\title{
Francisco Franco, articulista de incógnito (1945-1960)
}

\author{
Juan Carlos SÁNCHEz ILLÁN \\ Universidad Carlos III de Madrid \\ jcsanche@hum.uc3m.es \\ Daniel LuMBreras MARTÍNEZ \\ Universidad Carlos III de Madrid \\ jcsanche@hum.uc3m.es
}

Recibido: 12 de febrero de 2016

Aceptado: 11 de abril de 2016

\begin{abstract}
Resumen
Se trata de un análisis pormenorizado de los artículos publicados por Francisco Franco en el periódico Arriba entre los años 1945 y 1960 bajo los seudónimos de Jakim Boor, Hispanicus y Macaulay. Se lleva a cabo su disección en dos grandes categorías: enemigos del Régimen y política, economía y sociedad. Para ello, se toma como ejemplo el propio artículo de Hispanicus titulado "Lo político, lo económico y lo social". En la primera de las dos grandes categorías se agrupan todos aquellos elementos abstractos -instituciones o ideologías- que Franco consideraba perjudiciales para la España que él gobernaba o que históricamente habían sido hostiles a este país; en la segunda se recogen el comentario sobre política en términos actuales o generales, las situaciones económicas y sociales así como los numerosos fragmentos de Historia de España que el dictador gustaba de incluir en sus colaboraciones periodísticas.
\end{abstract}

Palabras clave: dictadura; prensa; opinión; propaganda; censura; masonería.

\section{Francisco Franco as a secret writer (1945-1960)}

\begin{abstract}
It presents a detailed analysis of the articles published by Francisco Franco in the newspaper Arriba between 1945 and 1960 under the pseudonyms Jakim Boor, Hispanicus and Macaulay. Its dissection is carried out in two broad categories: enemies of the Regime and policy, economy and society. To do so, is taken as an example the own article of Hispanicus titled "Lo politico, lo económico y lo social". In the first of the two broad categories are grouped all the abstract elements -institutions or ideologiesthat Franco considered harmful for the Spain that he ruled or which had been historically hostile to this country; the second includes commentary on politics in current or general terms, economic and social situations, as well as the numerous fragments of history of Spain that the dictator liked to include in his journalistic collaborations.
\end{abstract}

Keywords: dictatorship; press; opinion; propaganda; censorship; masonry.

\section{Referencia normalizada}

Sánchez Illán, J.C. y Lumbreras Martínez, D. (2016). Francisco Franco, articulista de incógnito (19451960). Historia y Comunicación Social. Vol 21, número 1, páginas 39-74. 
Sumario: 1. Introducción. 2. Metodología. 3. Franco, articulista de incógnito. 4. Qué: escribiendo sobre el mundo y los enemigos. 5. Hispanicus y Macaulay: "Lo político, lo económico y lo social". 6. Críticas, alusiones y repercusión de los artículos periodísticos de Franco. 7. Conclusiones. 8. Referencias bibliograficas. 9. Indice general de los artículos de Franco.

\section{Introducción}

Lejos de las pasiones que todavía suscita su figura y de los aspectos más conocidos de su vida y de su obra, este estudio se propone poner el foco sobre uno de las facetas menos estudiadas de Francisco Franco: su labor periodística como colaborador del periódico oficioso de la primera etapa de su régimen, Arriba. Su objeto de estudio será, pues, el análisis detenido de los textos periodísticos elaborados por Franco y publicados en el mencionado periódico. Más concretamente, persigue los siguientes objetivos específicos: describir de qué trataban los artículos; indagar cómo se elaboraron, entregaron, revisaron y difundieron; investigar cuándo se publicaron las colaboraciones y cuántas fueron; dilucidar quién ayudaba al autor en la redacción; indicar en qué medios de comunicación vieron la luz estos escritos y, dentro de ellos, en qué lugar; exponer por qué se escribieron; averiguar qué efecto tuvieron, así como relacionar los escritos periodísticos de Franco con sus antecedentes vitales y literarios.

Con carácter previo a la investigación, y teniendo en cuenta los objetivos planteados, se postulan las siguientes hipótesis para cada uno de ellos:

- Primera. Franco creía que judíos, masones y comunistas eran una amenaza grave para España y dedicó la mayor parte de su obra periodística a denunciar sus actividades.

- Segunda. Los artículos se redactaron de manera muy discreta, casi secreta.

- Tercera. Dejó de escribir finalizada la etapa de aislamiento internacional de España.

- Cuarta. El dictador se situaba en la cúspide el sistema informativo, que quedaba bajo su absoluto control.

- Quinta. Elaboró sus opiniones periodísticas él solo.

- Sexta. Sus contribuciones aparecieron en el diario Arriba en una posición poco llamativa.

- Séptima. Franco escribía por puro entretenimiento.

- Octava. Las colaboraciones provocaron algunos incidentes diplomáticos.

- Novena. Los artículos del entonces Jefe del Estado estaban fuertemente condicionados por sus experiencias vitales y son similares a su obra literaria anterior.

- Décima. Franco trataba temas de actualidad. 


\section{Metodología}

En el presente trabajo, debido al tiempo transcurrido y a la escasa difusión de los escritos que son objeto de estudio, se emplea la entrevista en profundidad a aquellos expertos que sean capaces de ofrecer información y datos de interés sobre el contenido, la realización y el contexto de los artículos de Francisco Franco. A este respecto, a menudo hay que enfrentarse a cuestiones complejas o tesis ampliamente discutidas. Para alcanzar la mayor fiabilidad posible, se emplearán los métodos del test-reset, que recomienda la repetición de las mediciones, y el de las mitades, "por el cual se aconseja efectuar más de una medición de cualquier concepto social o complicado, como pueden ser los prejuicios o la clase social" (García Galera y Berganza, 2005: 37). Mediante la entrevista se obtendrá "la reconstrucción de acciones pasadas... o, más bien, el análisis retrospectivo de una acción o un acontecimiento social" (Sierra, 1998: 309). Asimismo es útil para complementar el estudio cuantitativo. Se buscará entonces a observadores privilegiados, "sujetos no como parte del fenómeno estudiado, sino como conocedores expertos del fenómeno, con una visión directa y profunda del mismo que los sitúa en una posición de observación privilegiada" (Corbetta, 2007: 358).

El objeto específico de este estudio es cada uno de los 91 artículos que, bajo tres seudónimos distintos, escribió Francisco Franco en el diario Arriba desde 1945 hasta 1955, más uno aislado en 1960. Es un análisis sin base gramatical, de artículos enteros, en el que se busca referir tendencias en el contenido de estos actos comunicativos. "A partir de estas manifestaciones lingüísticas, se formulan inferencias sobre significaciones no lingüísticas" (Ander-Egg, 1997: 331-333). También el análisis de contenido para "realizar inferencias acerca de las causas, de los productores, o de los antecedentes de las comunicaciones... consecuencias o efectos" (López Aranguren, 2007: 558-559).

En esta técnica de investigación se distinguen como unidades de codificación las categorías, las cuales "son características o aspectos que presentan aquello a lo que se refiere el escrito con el que estamos trabajando" y, mediante la categorización, "clasificamos los elementos constitutivos de un conjunto por diferenciación a partir de criterios previamente establecidos" (Sánchez Aranda, 2005: 217). A su vez las categorías cuentan con subunidades, las variables. En conjunto, se realizará en este trabajo una tabla de distribución de frecuencias con las distintas categorías y sus variables, para después analizar las relaciones entre ellas, un método que ha alcanzado altas cotas de desarrollo y difusión (López Aranguren, 2007: 567). Se ha venido diciendo que las categorías están sujetas al principio de exclusión mutua, pues se definen por su unicidad y oposición al resto; además, se requiere que sean homogéneas, pertinentes respecto al propósito del estudio y claras (Sánchez Aranda, 2005: 218-219).

En cuanto a la trascendencia histórica de los efectos de la persuasión mediante la práctica propagandística, han sido fundamentales, para su conceptualización, en el marco español y comparado en su entorno de influencia geopolítica, las aporta- 
ciones germinales, para el caso de España, de Alejandro Pizarroso (1989, 1999 y 2002). El análisis del marco referencial, la perspectiva global y comparativa del fenómeno propagandístico ha seguido, a partir de los referidos trabajos de Pizarroso, una vía fructífera, con aportaciones sobre el papel de la propaganda anticomunista en el contexto internacional de la Guerra Fría (Duarte, Veiga y Ucelay, 2006), o más recientemente la obra colectiva dirigida por Antonio Niño y José Antonio Montero sobre el liderazgo estadounidense en esa labor de propaganda y cruzada cultural (2012).

Sobre la fascinación que ejercieron los fascismos en la década de 1930, es imprescindible la obra de Laurence Rees (2013), vital para entender las retóricas de los liderazgos autoritarios -en los casos portugués, italiano y alemán- y que sigue, a su vez, la senda abierta por la más que provocadora tesis de Daniel Goldhagen en Los verdugos voluntarios de Hitler. Los alemanes corrientes y el Holocausto (1997).

En especial, resulta esclarecedor el establecimiento de analogías con el proceso de construcción del régimen portugués de Salazar, en torno a la mitificación de la figura del Caudillo. En este ámbito ha sido ineludible contar con la aportación de Helena Matos (2003) Salazar, publicada en dos volúmenes, $A$ construção do mito y $A$ Propaganda; así como los trabajos, de ya largo alcance y recorrido, de Alberto Pena Rodríguez (2008 y 2013). Desde la perspectiva italiana, ha sido muy útil también el trabajo de Laura Zenobi (2011) La construcción del mito de Franco, en el que se muestran en detalle las distintas variables del proceso de auténtica invención y mitificación aludido.

Además del desarrollo del plan de trabajo y de la exploración detenida de las fuentes consultadas, hay que subrayar, asimismo, que este trabajo no hubiera sido posible sin la inestimable colaboración de todos los expertos entrevistados, así como muy en especial sin las aportaciones impagables de la profesora de la Universidad Carlos III de Madrid Matilde Eiroa San Francisco, gran especialista en el objeto de estudio, excelente colega y siempre eficaz cómplice en el devenir de esta investigación. Finalmente, hay que señalar que este artículo forma parte de las tareas del proyecto de investigación financiado por el Ministerio de Economía y Competitividad de referencia HAR2015-63582-P del que es IP la profesora Eiroa.

\section{Franco, articulista de incógnito}

Francisco Franco, además de militar y Jefe del Estado español, fue un activo colaborador de prensa: ejerció como director de la Revista de Tropas Coloniales (Ceuta, 1924-25), llamada más tarde África (1926-36). Ostentó además, desde 1937, el cargo de Presidente de Honor de la Asociación de Prensa de Madrid y figuraba en el Registro Oficial de Periodistas con el número uno. Asimismo fue colaborador de Arriba, tema del que se ocupa sustancialmente este trabajo. 
Gracias a la imprescindible biografía Franco, Caudillo de España se conocen los periódicos que leía antes de la Guerra Civil: $A B C$, La Época y La Correspondencia Militar (Preston, 2004: 107). Carlos Fernández Santander refiere que, ya instalado en el poder, "por las mañanas hojeaba el diario $A B C$ antes de ir a su despacho, así como un resumen de los demás periódicos que le pasaba su secretaría de prensa. Por la noche, antes de dormirse leía un buen rato en la cama" (2005: 396). El director de Arriba, Ismael Herráiz, presumió una vez de que su periódico era el primero que Franco leía por la mañana. Hubo, en especial, una publicación que le marcó: en 1928 le regalan una suscripción a una revista antibolchevique publicada en Ginebra, el Bulletin de L'Entente Internationale contre la Troisième Internationale, publicación que alimentaría su fobia al marxismo y le llevaría a considerar a todos los izquierdistas españoles siervos de Moscú. "Esa suscripción -según Paul Preston- afianzó en Franco una permanente obsesión por el anticomunismo. También influyó en la transición del soldado aventurero de los años veinte al general suspicaz y conservador de los años treinta. Al recibir el boletín sin interrupción hasta 1936, llegó a ver la amenaza comunista por todas partes y creía que toda la izquierda española trabajaba consciente o inconscientemente para los intereses del Komintern" (2004: 88).

Franco fue el Primer Periodista de España, no solamente porque así figurase en el Registro Oficial de Periodistas: recibió el nombramiento con todos los honores de manos del Director General de Prensa Tomás Cerro Corrochano, en un acto celebrado en el Pardo al que acudieron los principales directores de medios y otros personajes del mundillo periodístico el 20 de julio de 1949. No se lo dieron entonces por sus artículos -no se había hecho pública su autoría- sino por su trayectoria periodística de juventud en Marruecos y los discursos de la Guerra Civil (Luis de Galinsoga, "Un periodista auténtico", La Vanguardia Española, 21 de julio de 1949: 1). Franco recibió, además del carnet profesional -personalizado con su escudo heráldico-, un álbum con los periodistas “caídos por Dios y por España”. En su discurso de aceptación, animó a los periodistas a "continuar sirviendo al país en su labor de contar la verdad y alimentar el espíritu de los españoles", y recordó orgullosamente su labor periodística de juventud, "ejercida por necesidad" $(A B C$, "Homenaje del periodismo español al jefe del Estado”, 21 de julio de 1949: 7-9).

Al comienzo de la publicación de los artículos (1945) la redacción del diario en el que aparecían, Arriba, se situaba en la calle Larra, 8. Lo dirigía Javier Echarri y Gamundi (carnet de periodista $\mathrm{n}^{\circ} 25$ ), con Ismael Herráiz Crespo como segundo de a bordo (carnet $\mathrm{n}^{\mathrm{o}}$ 21). El caricaturista era Joaquín Alba Santizo, Kin, que ocasionalmente trazó caricaturas de acompañamiento a las colaboraciones. Arriba era el órgano de la Falange Española Tradicionalista y de las JONS, partido único que inspiraba la política del régimen, el diario casi oficial durante la primera etapa del mismo. Ferozmente antimonárquico, consideraba que esa forma de gobierno podía derivar en marxismo y dio cabida en su seno a la propaganda falangista contra el conde de Barcelona, con el consentimiento de Franco. En cuanto a su estilo, "tenía un sello especial, se daban cita en él todos los tópicos al uso como el nacional-sindicalismo, la unidad entre los hombres y las tierras de España...y se reflejaba en sus 
páginas el visceral odio al comunismo y el desprecio hacia las democracias occidentales" (Barrera, 1995: 64-65). Espejo y faro de la ideología conveniente para el régimen, en esta misión evangelizadora Arriba contaba con el apoyo de los demás diarios del Movimiento. Sus primeros directores, Echarri (1939-1949) y Herráiz (1949-1956) contaron con literatos de primera fila en sus páginas, además de Franco con sus seudónimos y su estrecho colaborador Carrero Blanco, tras los nombres de Ginés de Buitrago y Juan Español.

Es prácticamente imposible tener cifras fiables de tirada de este diario, ya que en aquel momento todavía no existían auditorías independientes -la OJD no se crea hasta 1964- y las empresas periodísticas ocultaban celosamente ese dato como un "secreto comercial, por temor a que las cifras reales de tirada las desacreditasen ante el mercado publicitario y ante sus propios lectores" (Sevillano, 1997: 326 y 329). Lamentablemente este periódico no ha sido estudiado de forma monográfica y solo existen datos fragmentarios. Por ejemplo, Sánchez Aranda y Barrera afirman que "llegó -parece- incluso a los cien mil ejemplares en los años cuarenta, pero al decaer el primer fervor de la posguerra fue cayendo poco a poco sin remedio a partir de 1950 (1992: 442). Por otro lado, Nazario González precisa que en 1945 rondaba los ciento cuarenta mil ejemplares. Pero en 1960 eran ya poco más de cincuenta mil (1995: 394).

Contrariamente a lo que cabría esperar del diario predilecto de la dictadura, un informe inédito del director Herráiz, fechado en 1956 y reproducido parcialmente en Aqui hubo una guerra, desvela las condiciones precarias en las que se trabajaba en sus instalaciones (Aguinaga, 2010: 130-131). Juan Velarde, colaborador de Arriba desde 1952, afirma que el periódico arrojaba pérdidas y era subvencionado por la Cadena de Prensa del Movimiento con los beneficios de los diarios más prósperos. A los malos resultados, según sus palabras, "contribuían el enorme plantel de colaboradores muy bien pagados (Eugenio D’Ors, Ramón Gómez de la Serna...) y la escasez de la publicidad por motivos estéticos y políticos". Enrique de Aguinaga reconoce que la tirada del diario era escasa, "pero esos ejemplares están en los ministerios, en las cancillerías, en los centros de poder..."

Francisco Franco publicó, bajo tres seudónimos distintos -Jakim Boor, Macaulay e Hispanicus- un total de 91 artículos en el periódico Arriba de Madrid, desde el primero, "Política clara" (Hispanicus, 9 de marzo de 1945: 1-4) hasta el último, "La masonería no descansa" (Boor, 27 de marzo de 1960: 17-18). Los artículos podían aparecer cualquier día de la semana -excepto, por supuesto, el lunes, ya que debido al descanso dominical obligatorio no se editaba el Arriba ese día- y carecían de una periodicidad fija: tan pronto se publicaba una serie durante varias semanas seguidas para luego parar durante un mes, como el flujo paraba un año entero o salían dos colaboraciones en una misma semana. Eso sí, casi todos aparecían en la portada del diario, en un lugar bien visible, ya fuera en la parte superior o en la inferior, con el título en una fuente de tamaño destacado. Solamente en tres ocasiones se incumplió esta regla: (Boor, "Campaña antijesuita", 1 de octubre de 1950: 5; Boor, "La causa de El Escorial", 22 de octubre de 1950: 3; Boor, "La masonería no descansa", 27 de 
marzo de 1960: 17-18). Cuando un artículo era muy largo, lo cual sucedía frecuentemente, comenzaba con una o varias columnas en la portada y finalizaba en el interior del periódico (Macaulay, "Memento", 6 de febrero de 1947: 1 y 3).

Francisco Franco nunca acudía personalmente a la redacción de Arriba para entregar sus colaboraciones, sino que los artículos seguían una singular andadura. Enrique de Aguinaga, entonces joven redactor del periódico que recibió de Ismael Herráiz -el ya referido director del diario entre 1949 y 1956- el encargo de ejercer como corrector de alguno de ellos, relata cómo era el proceso. "El ministro de Educación llamaba a Ismael Herráiz y le anunciaba que iba a enviar el artículo. Los traía un motorista y venían escritos en hojas grandes, de un papel de mucho gramaje (casi de cartulina), mecanografiados y con correcciones manuscritas con la letra de Franco (porque la letra de Franco la conocíamos perfectamente). Así, se mandaban al taller, a un linotipista que ya estaba encargado de ello. A los artículos de Franco se les daba el trámite normal: pasaban a la imprenta y en vez de ir a los correctores me los mandaban a mí. Luego seguían el trámite ordinario de enviar las galeradas a la censura". El motorista, precisa Antonio Gibello, compañero de redacción de Aguinaga, pertenecía a la guardia personal del dictador El papel, de gran cuerpo, pasaba por una doble corrección en la redacción (Aguinaga, 2002: 16). En una ocasión, como se verá más adelante, un artículo de Franco fue devuelto a la redacción con tachaduras del lápiz rojo de los censores. "Nunca hubo contacto directo del Caudillo con la redacción -refiere su corrector-, supongo que el artículo se lo entregaba al ministro de Educación en los despachos que tenían los ministros con Franco y le diría: 'Ibáñez, este artículo para que lo mande usted al director de Arriba"'. Aguinaga añade que Franco no se interesaba por la suerte de sus colaboraciones y que un día simplemente dejó de enviarlas, de modo que "no tenía que dar ninguna explicación, ni para mandarlos ni para retirarlos. El artículo venía a través del ministro y un día dejó de venir, y de la misma manera que no se daba el periódico por enterado, el director de Arriba no llamaba ni decía: 'Oiga don Francisco, que hemos recibido este artículo, muy bueno por cierto"".

El profesor Velarde asegura conocer la causa por la que Franco dejó de escribir artículos de temática económica, en los que defendía un vago keynesianismo. Después del que sería último en este ámbito (Hispanicus, "Realismo", Arriba, 15 de julio de 1949: 1 y 6), se produce una brusca interrupción. Ello se debería -en palabras de Velarde- "a la publicación de un monográfico de la revista Economía, editada por la Dirección General de Sindicatos, en la que un grupo de economistas españoles se preguntaba si era aplicable a España la Teoría General de Keynes. El dictamen era desfavorable, y cuando el Delegado Nacional de Sindicatos le llevó el ejemplar en una audiencia, Franco lo leyó, se convenció de que sus concepciones eran erróneas y abandonó las colaboraciones sobre economía".

$\mathrm{Al}$ abordar la cuestión de por qué eligió esos nombres para sus seudónimos, Aguinaga aventura que Franco no meditó demasiado su decisión: "Macaulay es un famoso político británico Jakim Boor está en la historia de la masonería; e Hispanicus es solamente hispánico para España. No creo que hubiera sido objeto de una especial 
deliberación. Algún asesor le dijo algo al respecto, aunque él hacía las cosas muy personalmente, porque por ejemplo Franco no tuvo jefe de prensa. Hacía sus discursos, tenía algunos amanuenses, pero no tuvo nunca jefe de prensa. Había un titular, que era Lozano Sevilla pero su función principal era la de taquígrafo. Le nombró jefe de prensa por cubrir el puesto, pero podría haber sido cualquier figura del periodismo como Víctor de la Serna o Joaquín Arrarás".

En los artículos de temática económica, Juan Velarde cree que no había un informador específico, sino que los elaboraba el mismo Franco a partir de lo que leía en la prensa; prueba de ello serían los numerosos recortes con subrayado y apuntes que se conservan entre sus papeles.

La autoría misma de los artículos no está exenta de controversia. Numerosas fuentes de autoridad consideran que Franco pudo contar con ayuda para escribirlos. El abogado José Luis Jerez Riesco, prologuista de una recopilación de los artículos, refiere que Franco redactaba sus textos, "con la colaboración de Carrero Blanco" y "con algunas insinuaciones de Giménez Caballero" (2003: 16). Ferrer Benimeli, en la misma línea, apunta que "los artículos de J. Boor eran guiones elaborados por Ernesto Giménez Caballero a petición de Franco quien, después, los desarrollaba a su gusto con la colaboración de Carrero Blanco" (1982: 315). Ernesto Giménez Caballero escribió para Franco -según su propio testimonio-, por encargo de Serrano Suñer, el llamado Discurso de la Unificación en 1937 (1979: 100). Sin embargo, parece improbable que colaborase habitualmente con el dictador, dado que progresivamente se fue alejando de las esferas de poder. "La misma marginación política de Giménez Caballero en la España franquista resulta muy ilustrativa -señala al respecto su biógrafo Enrique Selva-. El punto culminante lo alcanzó en abril de 1937, cuando... Franco lo nombró miembro de la Junta Política. A partir de entonces inició su declive... Con la caída de los fascismos en $1945 \ldots$ era ya un personaje absolutamente marginado en la cultura española" (2000: 289-290). Cabe la posibilidad de que el escritor le sugiriese ideas a Franco cuando lo acompañó a una visita oficial a Portugal en 1949 (Giménez Caballero, 1979: 190-192), pero resulta sumamente extraño que no incluyese en sus Memorias de un dictador un acontecimiento de tal calado como contribuir a los artículos del Caudillo. Enrique de Aguinaga asegura que el escritor fascista no participó en el proceso: "Giménez Caballero descartado por completo. Franco lo manda al Paraguay. Fue profesor mío, autor de La Edad de Plata y un gran personaje literario. Pero no le veo de amanuense".

En cuanto al Almirante, la ascendencia de Carrero sobre Franco es bien conocida. Este fiel colaborador le influyó enormemente desde los años de la Segunda Guerra Mundial y compartía con él la preocupación por la expansión del comunismo ruso y el supuesto antiespañolismo militante de la masonería internacional. Carrero se oponía también a los cambios internos en el régimen, esgrimiendo tres armas, las dos primeras muy presentes en los artículos de Franco: "nuestro catolicismo, nuestro anticomunismo y nuestra posición geográfica" (Tusell, 1993: 107-117, 151). 
Es cuanto menos curioso que en los archivos de Carrero Blanco, situados en Presidencia del Gobierno, se encuentren los artículos de Franco con el seudónimo de Jakim Boor, así como instrucciones del marino para artículos de fondo en el Arriba, donde escribió él también con el seudónimo de Juan de la Cosa. "Merece la pena recalcar", argumenta Tusell, "que siendo ambos taxativos defensores de la tesis de la conspiración masónica, a la que atribuían todos los males a lo largo de la Historia de España y en contra del régimen, da la sensación de que Franco era más insistente y repetitivo sobre el particular". Además, recalca las diferencias entre el estilo literario del dictador y de su colaborador. "Lo cierto es que Carrero tenía una superior fluidez de pluma que Franco y también un bagaje ideológico más asentado y, por ello mismo, más difícil de modificar" (1993: 138). Alberto Reig afirma sin dudas que los artículos de Boor fueron elaborados por Franco en colaboración con su siempre leal Carrero (2005: 308). Ricardo de la Cierva, por su parte, apunta una última hipótesis sobre los artículos de Boor, al señalar que "Joaquín Arrarás, el primer biógrafo de Franco, no era ajeno a su redacción o corrección" (1979: 467). Aguinaga afirma que este tercer personaje le parecería posible, si bien ve más plausible la hipótesis de Carrero Blanco y que "tal vez fuese el marino quien lo escribía primero y el Caudillo el que lo corregía después". Enrique Moradiellos apunta sobre este particular que "es muy plausible que Franco confiara en Carrero para esas labores porque es lo que hacía para casi todo desde mayo de 1941, cuando asumió la subsecretaría de Presidencia y empezó a operar como un ayudante de general en un Estado Mayor. Por tanto, en principio, la afirmación de Ricardo de la Cierva tiene verosimilitud, que ya es bastante. Y teniendo en cuenta que el autor entrevistó a Franco para su biografía, esa afirmación no es del todo descartable". Contradiciendo las conjeturas anteriores, Bernardino Martínez Hernando, archivero y bibliotecario de la APM, se muestra convencido de que "ni Franco se hubiera dejado ni Carrero se prestaba... Otra cosa es que hablaran, que comentaran, pero cada uno escribía sus artículos -por lo menos las noticias que yo tengo- porque cada uno en el tema que escribía sabía o creía que sabía lo que decía. Como documentación no lo necesitaban, cada uno tenía su propia documentación". Luis Suárez asegura al respecto que le consta que los dos "intercambiaban ayudas en sus respectivos artículos con seudónimo".

Paul Preston, aunque se hace eco de la posibilidad de la intervención de Arrarás, parece inclinarse por la posibilidad de que escribiese en solitario (2004: 613-614). Fernando Díaz-Plaja mantiene que era Franco quien escribía sus propios discursos, ya que es la única explicación para que siempre mencione a los mismos enemigos -marxistas y masones- desde su primera entrevista al News Chronicle en 1936 hasta el último discurso en la Plaza de Oriente poco antes de su muerte, arengando con contenidos y sintaxis similares (1997: 42). El profesor Velarde es también partidario de la hipótesis de la autoría única. "Escribía el solo seguro -afirma-, a él le apetecía escribir solo desde la Revista de Tropas Coloniales. Quien diga eso [que tenía ayudantes] ignora cómo era Franco. A él le gustaba escribir en los periódicos. Se limitaba por motivos políticos" . Por otro lado, al día siguiente de la muerte del dictador, entre los muchos elogios que le dedicó, el diario Arriba exhibió orgulloso algunos de sus artículos con la siguiente introducción: "Durante los años cuarenta Francisco Franco desarrolló una de sus 
mayores aficiones... el periodismo activo... desde los seudónimos de Hispanicus, Jakim Boor y Macaulay hablaba al país de la política internacional, la masonería y la política nacional, respectivamente".

En el curso de esta investigación se han podido consultar los guiones mecanografiados de varios de los artículos. Estos aparecen con tachaduras, enmiendas y firmas de una caligrafía que, cotejada con otros documentos es inequívocamente la de Franco. En el primero de ellos el encabezamiento, difuminado, aparece tachado y en su lugar está escrito a mano el nombre de la colaboración, "Marruecos", firmado al final con Hispanicus. En el segundo de ellos, el guion de "Memento", figura al final la firma de Macaulay Hay varios de Jakim Boor, por ejemplo uno con el encabezamiento de "Masonería", sin fecha y que no se corresponde con ninguno de los publicados (tal vez sea un borrador); otro texto de la primera de las colaboraciones de este seudónimo, "Masonería y comunismo" (Boor, 1952: 11-16), aparece firmado como Jakim Boor (se percibe que la J está sobrescrita a una $\mathrm{H}$ ).

Llama, en primer lugar, la atención el deseado anonimato. "Por deseo expreso suyo, nadie, excepto algunos de sus Ministros y nuestros directores, Javier Echarri e Ismael Herráiz, conocían la auténtica personalidad de este articulista de excepción" se dice en la necrológica del número especial de Arriba de 21 de noviembre 1975. Su hija Carmen recuerda en sus memorias esta discreción: "Yo me enteré un poco más tarde [de que él era Jakim Boor]. No, no hablaba de eso. Hacía los artículos, pero yo creo que prefería que no se supiera que era él, por lo cual no hablaba de ello" (Palacios y Payne, 2008: 357). A pesar de lo expresado por el periódico, Aguinaga recuerda que el staff de la redacción sabía que Franco colaboraba en Arriba y los periodistas más perspicaces también se habían dado cuenta. Su colega Antonio Gibello manifiesta que en la profesión periodística era un dato bien conocido, no así para el público En cambio Juan Velarde se muestra convencido de que lo sabía todo el mundo. El estudioso de la masonería Juan José Morales Ruiz señala, en el mismo sentido, que "aunque hubo muchas dudas sobre quién era realmente el auténtico autor de los artículos, enseguida trascendió que emanaban de quien detentaba (no ostentaba) la máxima autoridad del Estado" (2004: 1273). En cuanto a su alcance internacional, Luis Suárez cree que el gobierno estadounidense sabía perfectamente que era Franco quien estaba detrás de los artículos y que los yanquis -azuzados por el New York Times- escribieron miles de cartas de protesta a la Casa Blanca (1984: 433); y Preston, asimismo, apunta que el Ejecutivo británico también estaba al tanto, aunque "cabe dudar que a Franco le importara" (2004: 645).

Sopesados los diversos testimonios, sigue sin quedar suficientemente claro si la población española sabía que Franco publicaba artículos en Arriba, pero a falta de suficientes evidencias documentales cabe suponer que no era un conocimiento de dominio público. Con todo, para acallar los rumores sobre este asunto, el entorno de Franco ideó un peculiar desmentido. Entre los nombres de las personas recibidas en audiencia civil por el Jefe del Estado, de cuya lista se hicieron eco diversos medios de comunicación, colaron a Mr. Jakim Boor ("El jefe del Estado recibió a los representantes de los congresos de Pediatría y Terapéutica", $A B C, 9$ de octubre de 
1952). Asimismo, hay una consignación de los derechos de autor de Boor por valor de treinta y nueve mil novecientas setenta y tres pesetas con cincuenta céntimos al Delegado Nacional del Frente de Juventudes para destinarlo a caridad, con fecha del 27 de octubre de 1952. Es curioso que el cheque sea "con cargo a la cuenta de la Administración General de los Fondos del Ministerio de Información y Turismo" y no de una cuenta privada del supuesto autor Incluso, apunta Aguinaga, después se llegó a simular su muerte y se publicó la esquela de Jakim Boor en la prensa:

Se puede, finalmente, deducir cierta voluntad de estilo y de difusión de sus ideas en el hecho de que las colaboraciones de Jakim Boor fueron reunidas en un tomo bajo el título de Masonería en 1952, publicado por Gráficas Valera en vez de la Editora Nacional como cabría esperar y al margen del diario Arriba. Enrique de Aguinaga apunta que posiblemente fuese una iniciativa de Carrero Blanco

\section{Qué: escribiendo sobre el mundo y los enemigos}

Figura 1: Distribución de los artículos en las dos categorías.
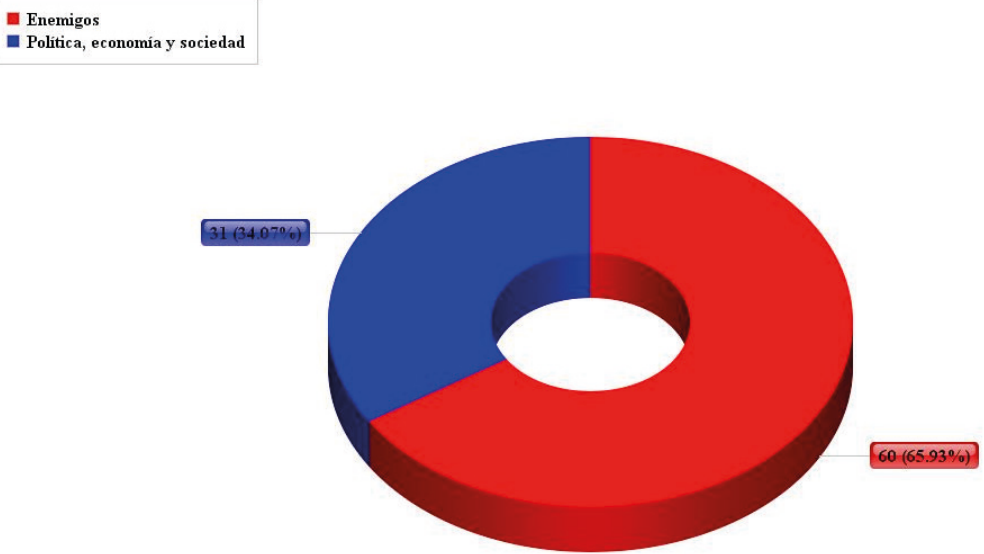

Fuente: Elaboración propia

Los resultados del análisis de contenido, con los pertinentes comentarios y las aportaciones testimoniales de los expertos sobre cada uno de los 91 artículos analizados, muestran que la categoría de Enemigos es la que más entradas acumula, con 60 de las 91 colaboraciones analizadas (casi un 66 por ciento). Franco veía por todas partes, tanto en el pasado como en el presente de España, multitud de enemigos unidos, hostiles y envidiosos al otrora esplendoroso Imperio hispánico y al régimen actual. Así, glosa Luis Suárez que ya desde el primer artículo de Jakim Boor "se proponía demostrar de qué modo el ataque contra su Régimen no era otra cosa sino el resultado de una confluencia entre dos fuerzas, masonería y comunismo" (1984: 
140). A ello añade el hispanista Bennasar que Franco veía en todas "las desgracias de España y la elaboración de la política mundial los efectos de una perpetua conjura de los masones, aliados según las exigencias del momento a los comunistas, los socialistas, incluso los judíos". Para el general, esos enemigos "forman parte de una especie de delirio interior. Es un fantasma frío que alimenta con perseverancia" (1996: 300).

Figura 2: Distribución de impactos de las distintas variables de la categoría "Enemigos".
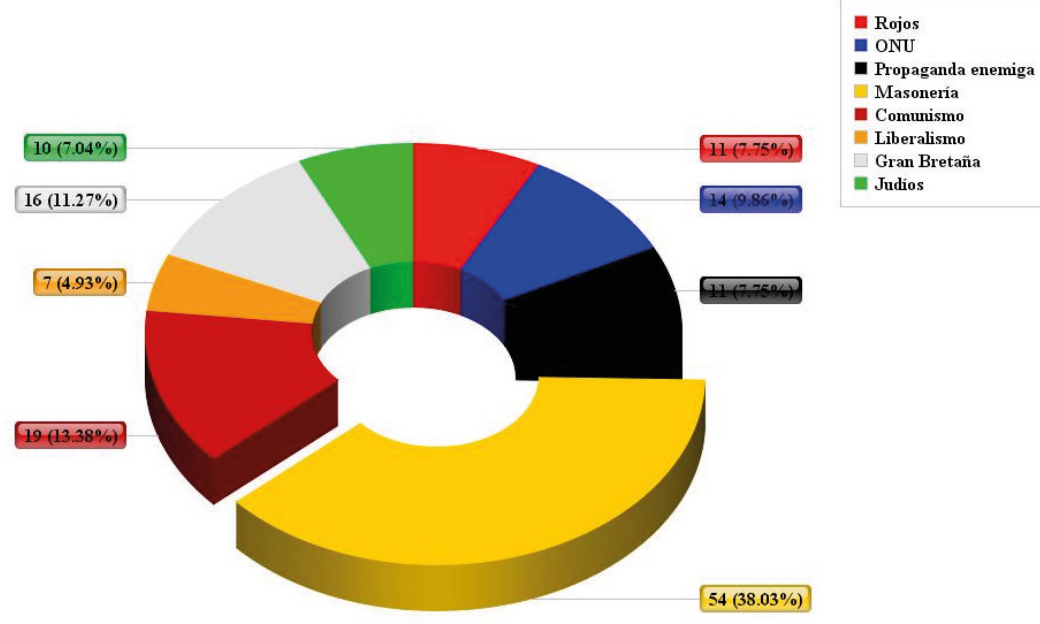

Fuente: Elaboración propia

Esta conspiración conjunta de la anti-España era lo que se denominaba comúnmente contubernio, idea que acompañaría al dictador hasta el último de sus mensajes a los españoles, pronunciado en la Plaza de Oriente de Madrid el 1 de octubre de 1975. De acuerdo con la tesis de Javier Domínguez Arribas (2009), esta idea del contubernio no es ni mucho menos algo exclusivamente español ni franquista. De hecho, los sublevados de 1936 no hicieron más que actualizar los viejos temas que los propagandistas católicos reaccionarios llevaban difundiendo desde hacía décadas.

El propio Jakim Boor lo expresa así en "Acciones asesinas": "Judaísmo, masonería y comunismo son tres cosas distintas, que no hay que confundir, aunque muchas veces las veamos trabajar en un mismo sentido y aprovecharse unas de las conspiraciones que promueven las otras" (1952: 219). En opinión de Javier Tusell, Franco probablemente pensaba que las conspiraciones existían en la realidad y añade que "la masonería aparecía, en su forma de ver las cosas, vinculada al liberalismo y éste a su vez, de modo necesario, llevaba a la subversión comunista. La masonería encerraba una dosis suplementaria de peligrosidad porque, a diferencia de la clara subversión revolucionaria, podía conseguir ocultar sus propósitos decisivos bajo una apariencia inocua... lo más probable era que Franco creyera sinceramente lo que afirmaba" (1996: 123-124). 
El comunismo está bastante presente en los artículos: este enemigo aparece en diecinueve de ellos (31 por ciento dentro de la categoría, 20 por ciento del total). Hispanicus no diferenciaba entre las distintas variantes del marxismo. "Para nosotros -afirmaba-, socialismo y comunismo son escalones en una misma marcha, al final de la cual el comunismo espera" ("Socialismo y comunismo", Arriba, 18 de febrero de 1949: 1). También opina que el comunismo ruso, para desgracia del mundo, se ha expandido con la guerra mundial, tras haber llevado a Rusia el fracaso económico y social ("La crisis del comunismo", Arriba, 22 de marzo de 1945: 1).

En España -escribe en "El gran secreto"- existe "una unión malévola entre el comunismo y la masonería que conspira contra la España nacional. Si en otras partes los campos del comunismo y la masonería aparecen claramente delimitados, y hoy en franca y abierta oposición, en el sector de los españoles viven en íntimo contubernio" (Boor, 1952: 37-38). Para combatir el peligro comunista -frente al que España es un firme bastión-, Franco llama a las naciones occidentales a plantar cara a Rusia para liberar el Este de Europa del yugo de la hoz y el martillo (Hispanicus, 1964: 25-31).

Hay muy poca literatura sobre Franco y el comunismo. Ahora bien, al hablar de Jakim Boor, Luis Suárez asegura que Franco consideraba al comunismo más peligroso incluso que la masonería y "de una manera constante sostendrá que la URSS, en cuanto vehículo para la expansión del marxismo, era el peligro principal que arrostraba el mundo, ya que el materialismo dialéctico destruye las raíces de la vida espiritual" (2005: 118). Para Franco, los españoles eran víctimas del sovietismo porque Stalin quería vengarse de la derrota en la Guerra Civil y del envío de la División Azul (Tusell, 1984: 100).

Gran Bretaña también es otro de los blancos predilectos de la ofensiva periodística de Franco, con dieciséis alusiones (casi un 27 por ciento en la categoría de enemigos). La pérfida Albión es el origen de la odiada secta, de la que Jakim Boor llega a decir incluso que está comandada por la Corona británica y se confunde con el Estado (1952: 94-97). Al parecer, Franco llegó a afirmar, en un Consejo de Ministros en 1945, que en el Reino Unido había nada más y nada menos que quince millones de masones, y que todos ellos habían votado al partido laborista, hostil al régimen (Tusell, 1984: 100). Franco acusaba a menudo a Inglaterra de mala vecindad y falta de moralidad, así como de entorpecer las relaciones del régimen con Estados Unidos: España es la malquerida de Inglaterra (Macaulay, "La malquerida", Arriba, 9 de julio de de 1948: 1). Aún más, en "Serenidad", Macaulay censura con dureza la política económica británica -pero sin atacar a los laboristas- y llama al pueblo inglés al sacrificio; asimismo se enorgullece de la serenidad y libertad de crítica en la prensa española (Arriba, 26 de agosto de 1947: 1).

La última etapa de las colaboraciones (1954-1955) coincidió con una campaña impulsada por Franco para recuperar Gibraltar, que se convirtió en objetivo prioritario. Franco creía que la actuación gubernamental en este asunto era inane, como le contó a su primo Pacón el 10 de diciembre de 1954. "No estoy conforme con la poca 
energía que tienen nuestras autoridades para enfrentarse con los ingleses", llegó a decir. (Franco Salgado, 1976: 47).

En "Siempre Gibraltar" el dictador daba comienzo a su particular lucha aireando la historia del conflicto, sacando a la luz que Winston Churchill había ofrecido al gobierno franquista la devolución del Peñón a cambio de la neutralidad en la Segunda Guerra Mundial, "promesa incumplida que ofende a los españoles" (Macaulay, Arriba, 21 de febrero de 1954: 1-2). La reina de Inglaterra, sin tener en cuenta estos ataques, visitó Gibraltar, provocando la respuesta dialéctica y física del régimen. Así ha narrado este episodio Preston: "Franco, profundamente irritado por la visita de la reina Isabel II a Gibraltar, escribió varios artículos virulentos en el periódico Arriba bajo el seudónimo de Macaulay. No obstante, silenció las protestas públicas más fuertes, en parte para disminuir la agitación en las universidades y también a causa de la clara declaración del embajador estadounidense de que la posición de Gran Bretaña y Gibraltar dentro de la OTAN aseguraba el apoyo de Estados Unidos a Londres en el tema del Peñón" (2004: 683). Sin embargo Macaulay, a pesar de oponerse al viaje oficial, exonera a Isabel II de toda responsabilidad y considera que son sus consejeros los que la mantienen engañada sobre la vergonzosa situación del Peñón ("Visita inconveniente", Arriba, 7 de marzo de 1954: 1-2). Para la historiadora Mirta Núñez, agitar esta bandera era una cuestión más retórica que práctica, de puro oportunismo: "En realidad -afirma- no creo que hubiera una voluntad real de recuperar Gibraltar, pero le venía muy bien para esa ideología hueca que tenía jalear la pérdida de Gibraltar y luego la recuperación, las dos cosas. Y de hecho cualquier acción en ese terreno queda en agua de borrajas".

Los judíos no parecen en principio una preocupación de gran magnitud en los artículos de Franco (10 menciones, el 16 por ciento dentro de la categoría de enemigos y un 11 por ciento del total de los 91 textos), sin embargo hay un debate historiográfico amplio sobre este asunto. El profesor de la Universidad de Tel Aviv Raanan Rein expresa, en este sentido, que el intento del régimen por integrarse en el entorno político favoreció la situación de los judíos: "Se trataba de una minoría tolerada. Hasta mediados de los años cincuenta, Franco afianzó una política que permitió a los judíos en España llevar una vida comunitaria y religiosa más o menos libre, aunque con ciertas restricciones, sobre todo con respecto a la visibilidad de sus sinagogas

Su correligionario Enrique de Aguinaga opina que Franco no se refería en sus artículos a los hebreos de a pie, sino a los poderosos. "Los judíos -según el ex redactor de Arriba- no eran, en el imaginario de Franco, los judíos sefarditas que salvó de la persecución nazi. Los judíos eran los judíos de Nueva York, las grandes oligarquías judías que gobernaban internacionalmente. Eso era lo judeomasónico, no los pobres judíos que salvaba Ángel Sanz Briz a través de la embajada... Los judíos eran el poder capitalista y el poder mafioso, las grandes internacionales judías" . Examinando de cerca los artículos, se comprueba que lo que más le molestaba es el Estado de Israel -el cual votó contra la entrada de España en la ONU-y el judaísmo internacional que odia a la religión católica (Boor, 1952: 66, 73 y 79). Tras este desencuentro con el Estado hebreo, el régimen franquista -como es bien sabido- vuelve los 
ojos hacia el mundo islámico, con el que se aliará, y su propaganda exaltará el tópico de la tradicional amistad hispano-árabe. El profesor Rein apunta que el dictador recelaba con fundamento: "No le faltaban razones a Franco para guardar cierta sospecha hacia el Nuevo Estado Judío. El Estado de Israel estaba baja la hegemonía de partidos socialistas/socialdemócratas hasta los años setenta. No se trataba de fuerzas políticas que le resultaban de su agrado. Su alianza política con la Iglesia Católica y los temas no resueltos del estatus de Jerusalén y de los Santos Lugares en la misma tampoco le alentaban a acercarse a Israel".

En "Acciones asesinas", Jakim Boor matiza que la culpa no es del judaísmo en general, sino de una minoría conspiradora unida a la masonería, como ya habían demostrado -para Franco- Los protocolos de los sabios de Sion (1952: 220-221). Es más, Joseph Pérez detecta cierta afabilidad hacia los judíos sefardíes de Marruecos ya en la Revista de Tropas Coloniales. "El régimen de Franco -en sus palabras-, a pesar de declaraciones ideológicas sobre el complot judeo-masónico y de la repetida aprobación del decreto de expulsión firmado en 1492 por los Reyes Católicos, se mostró, pues, bastante benévolo con los sefardíes y los judíos" (2005: 313 y 320). Probablemente lo fuera, al menos, con los judíos ricos de Marruecos que, según la tesis del historiador Isidro González (2009), apoyaron y financiaron su sublevación.

El liberalismo y la democracia son otro de los enemigos a batir. Franco odiaba la democracia liberal y el parlamentarismo. Los consideraba origen de males nefastos para un Estado. "El régimen liberal y de partidos -decía en 1943- para los españoles ha demostrado ser el más demoledor de los sistemas, incompatible con la unidad, la autoridad y la jerarquía" (Bardavío y Sinova, 2000: 181). Sin embargo, solamente en siete artículos (de los 60 que componen la categoría de enemigos, es decir, cerca de un 12 por ciento) cargaba las tintas específicamente contra esta figura política.

En cualquier caso, la masonería es el tema estrella y epítome de los artículos de Franco, con 54 repeticiones en enemigos (el 90 por ciento), lo cual supone un 59 por ciento respecto al total de artículos. Para él, esta organización era la causa de todos los males de España y de parte de Europa. En palabras de Fusi, "lo que había desvelado es que eran masones casi todos los políticos que en algún momento u otro habían dicho algo contra su régimen (Roosevelt, Churchill, Truman, Blum, el noruego Trygvie Lie... que toda la política del Reino Unido y Francia desde el siglo XVIII había sido dictada por la masonería; que la masonería perseguía la decadencia de España desde que la introdujera Felipe Wharton... en 1728 y a su mano se debía todo lo que en España había ocurrido desde entonces: el motín de Esquilache, la expulsión de los jesuitas, la pérdida del imperio, revoluciones y guerras civiles, la ferrerada de 1909, la caída de Maura, los crímenes políticos, etcétera" (1995: 129).

El gran experto en masonería Ferrer Benimeli ha apuntado a dos posibles causas para este odio. Una es la marginación que sufrió Franco a manos de militares masones durante la II República. La otra es que intentó entrar en la orden por dos veces (una en Larache en 1925 y otra en Madrid en 1932) y siempre fue rechazado por otros compañeros de armas (1977: 43). En cualquier caso, se trata únicamente de 
testimonios y jamás ha trascendido documento alguno que pruebe que Franco haya intentado ingresar en la masonería.

Las diatribas de Franco contra la masonería estaban a la orden del día. En "Los que no perdonan", de 1949, censura que hayan intentado triunfar en las elecciones de Portugal (Boor, 1952: 45-52); o en "El gran fraude democrático" en las de México (Ibídem: 67-72); acusa a los masones incluso de la inestabilidad política en Bélgica, en "El gran odio" o "Batallas políticas" (Ibídem: 61-66, 235-240) y de cometer asesinatos rituales en "Crímenes de las logias" (Ibídem: 115-120). El caso prototípico es el último artículo recogido en la recopilación de 1952, "La masonería actual", en el que esboza un compendio de todas las inmoralidades de la secta y les acusa de estar detrás de los recientes disturbios en Barcelona (Ibídem: 321-329) Asimismo son muy abundantes los artículos de corte histórico en los que Jakim Boor narra con todo detalle (fáctico; nunca describe apenas ambientes ni personas) las tropelías cometidas por la orden en el pasado. Por ejemplo, "Historia masónica" es prácticamente una noticia biográfica del malhadado Felipe Wharton, duque inglés al que Franco atribuye una vida de excesos y la fundación de la primera logia en España (Ibídem: 131-136). Tal era su odio hacia este personaje que, cuando visito su tumba en el monasterio cisterciense de Poblet en junio de 1952, obligó al abad a trasladar la lápida de la tumba de Wharton fuera de suelo sagrado (Ferrer Benimeli, 1977: 39). Una larga serie de artículos está dedicada a relatar la expansión y las calamidades provocadas por la masonería bajo el reinado de Carlos III: el motín de Esquilache, la infiltración en la Inquisición, la campaña contra los jesuitas... (Boor, 1952: 253-276, 293-300). Deseoso de unir a todos sus enemigos bajo una misma bandera, Jakim Boor llega a afirmar que "el carácter judaico de la masonería se acusa a través de su literatura y de sus ritos... el hebreo es antes judío que masón y subordina a su creencia y a su pasión judaica todos los intereses de la orden, no obstante lo cual aparece ocupando los principales puestos de la masonería" (1952: 140-141).

El siguiente enemigo, la ONU, aparece para Franco como un organismo odioso que intriga contra la respetable España, y se refiere despectivamente a ella hasta en catorce ocasiones ( 23 por ciento de la categoría de enemigos). En " ¡España es la que acusa!" Hispanicus niega toda autoridad sobre España a este organismo y se enorgullece de la neutralidad nacional durante la Segunda Guerra Mundial, frente a la subordinación de los rojos a Rusia en la Guerra Civil (Arriba, 3 de noviembre de 1946: 1 y 4). Por supuesto, la ONU está dominada por diplomáticos masones (Boor, 1952: 11-12) que votan contra España obedeciendo a las consignas de sus logias (Ibídem: 21-24). Además, la ONU está vinculada a la Asociación Masónica Internacional, a la que consulta antes de tomar cualquier decisión (Ibídem: 179-180).

Gran parte de las críticas a las Naciones Unidas se centran en su secretario general, el noruego Trygvie Lie, perteneciente a un grupo de "degenerados y delincuentes" (Macaulay, "Serenidad", Arriba, 26 de agosto de 1947: 1), además de "grado 33 de la masonería [el máximo], lo que no le priva, a su vez, de estar al servicio de Moscú" (Boor, 1952: 11). Franco no pierde ocasión para atacar a este supuesto doble agente, pues "el caso de Trygvie Lie es un ejemplo que no debe olvidarse" (Ibídem: 206). 
La propaganda enemiga obtiene algo más de atención que los judíos (once menciones). La inquina que Franco le profesa se debe a que mancha con mentiras el buen nombre internacional de España y su régimen, intentado destacar únicamente los aspectos negativos del mismo (Macaulay, "Constancia", Arriba, 18 de abril de 1948: 1). Actúa movida en multitud de ocasiones, a su juicio, por los otros enemigos, como por ejemplo la masonería, que insta a sus seguidores a desprestigiar a España en todos sus medios de comunicación (Boor, 1952: 44). Dentro de la propaganda, el blanco preferido del Caudillo es la BBC. En "Albión" acusa a la emisora británica de fabricar continuas calumnias hacia España y de acoger a comunistas y exiliados que actúan movidos por la envidia (Macaulay, Arriba, 4 de diciembre de 1949: 1).

Por último, dentro de los enemigos de España se incluyen en lugar preeminente los rojos, a los que Franco ataca tantas veces como a la propaganda enemiga. Los exiliados republicanos que, sin lugar a dudas para Franco, siguen maquinando para retomar España y reciben ayuda de sus otros enemigos: "Toda la protección que los rojos españoles encuentran en los medios internacionales tiene una misma explicación y un mismo origen: o son los masones los que los apadrinan y apoyan, o son las Embajadas soviéticas y sus agentes quienen los mandan y los financian" (Boor, 1952: 12-13). Entre ellos, ocupan un lugar destacado -como objeto de odio en los artículos- el siniestro José Giral, presidente del gobierno republicano en el exilio de 1945 a 1947 (Hispanicus, "España es la que acusa", Arriba, 3 de noviembre de 1946: 1) e Indalecio Prieto, el capitán Araña, al que otros países han acogido y los laboristas ingleses apoyado (Macaulay, "Servicios secretos", Arriba, 19 de febrero de 1950: 1).

\section{Hispanicus y Macaulay: "Lo político, lo económico y lo social”}

Figura 3: Distribución de impactos de las distintas variables de la categoría "Política, economía y sociedad".

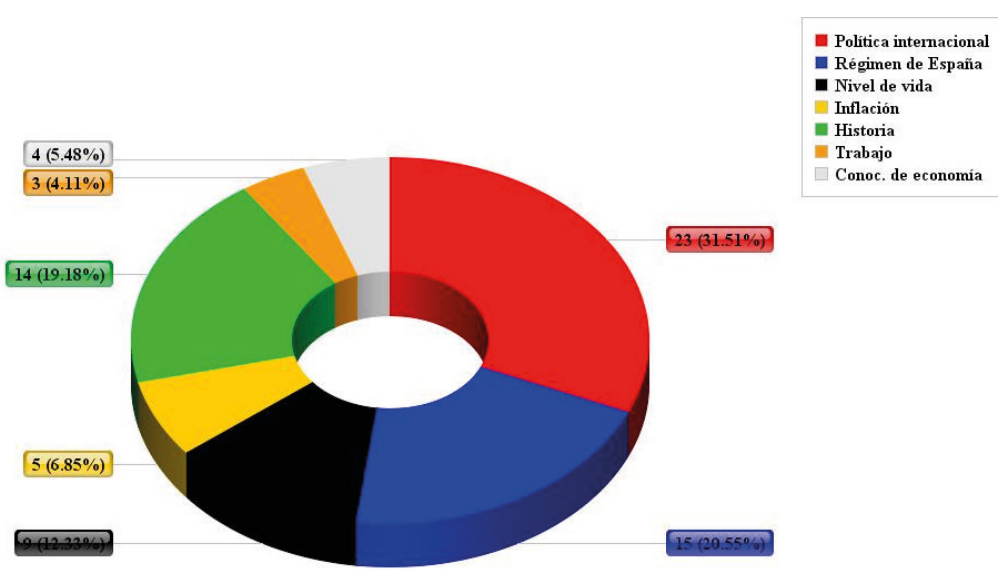

Fuente: Elaboración propia 
El título de este epígrafe está tomado de un artículo del propio Hispanicus, "Lo político, lo económico y lo social", en el que propugna que se deben abordar las tres cuestiones a la vez para mejorar España y defender el Imperio social y católico (Arriba, 1 de febrero de 1947: 1). Esta categoría tiene de particular que solo es abordada por los seudónimos Hispanicus y Macaulay -para asuntos internacionales-, nunca por Jakim Boor. Su importancia cuantitativa es menor que la de la primera categoría (treinta y un artículos de los noventa y uno, el 34 por ciento) y menos tratada por la literatura sobre Franco, pero a veces igual de combativa en sus escritos. El comentario de política internacional es la variable central de esta categoría, con veintitrés repeticiones ( 74 por ciento). Aquí Franco se permite a veces digresiones en tono pacífico, como la de "Sistemas políticos", en la que analiza las diversas formas de gobierno que sucedieron a la Gran Guerra y las complejidades de los pueblos; termina dictaminando que hay que juzgar a los regímenes por su naturaleza moral y no por contiendas bélicas (Hispanicus, Arriba, 14 de enero de 1947: 1). No falta espacio para criticar la soberbia inglesa que, en su decadencia, arrastra a los demás países (Macaulay, "Economía e inflación", Arriba, 29 de enero de 1947: 1). Ocasionalmente Franco ejerce de arbitrista, convocando al mundo occidental para liberar a las naciones sometidas al yugo del comunismo (Hispanicus, "Único camino", Arriba, 21 de marzo de 1948: 1) o incluso dar lecciones de política económica a Estados Unidos, cuyo proteccionismo juzga beneficioso para Rusia (Hispanicus, "Realismo", Arriba, 15 de julio de 1949: 1 y 6).

Los artículos de Franco como Hispanicus se inician defendiendo el régimen vigente en España, que acumula quince ítems en esta categoría (un 48 por ciento), siendo la apologética del franquismo la segunda variable más significativa. Ya en "Política clara", el primero de ellos, reivindica la Revolución que ha supuesto el Régimen frente a la vieja política y el caduco parlamentarismo anterior. Para Hispanicus, es un programa nacional con instituciones orgánicas, sin distinciones de izquierda o derecha (Arriba, 9 de marzo de 1945: 1 y 4). En "Meditación" se congratula de la pureza espiritual de una Revolución que camina "por el Imperio hacia Dios" (Hispanicus, Arriba, 30 de enero de 1947: 1). Opina también sobre la llevanza de las finanzas estatales en "El progreso económico", artículo en el que defiende la necesidad ocasional del déficit público y reclama una nueva ley tributaria (Hispanicus, Arriba, 9 de febrero de 1947: 1).

Las digresiones sobre el pasado son la tercera variable más repetida en esta categoría, con catorce ítems (un 45 por ciento). Escribe no solo sobre la historia de su país sino también la extranjera. Así, en "Memento" desarrolla la efemérides de la invasión de Finlandia por parte de Rusia, que no pudieron parar los voluntarios anglosajones (Macaulay, Arriba, 6 de febrero de 1947: 1 y 3). Franco recoge numerosas afrentas contra España, como las cometidas por Inglaterra en los últimos cien años (Macaulay, "La malquerida", Arriba, 9 de julio de 1948: 1). Un retrato sui generis sobre la Historia de España reciente puede hallarse en el artículo "Nuestra Revolución": la Restauración estuvo plagada de políticos ineficaces que perdieron la oportunidad de construir un Imperio, la Dictadura de Primo de Rivera fue beneficiosa para el país y 
la República fue poco menos que el Apocalipsis, dando lugar a que se empoderasen grandes enemigos de la Patria como las logias, el comunismo y el ateísmo (Hispanicus, Arriba, 15 de enero de 1947: 1).

La economía es otra de las grandes temáticas de esta categoría. Las finanzas públicas se encontraban en un estado pésimo: en los años cuarenta el déficit público aumenta, la deuda sube, las divisas se agotan y la producción se estanca. La señal más clara del fracaso de la política económica es que habrá que esperar a 1952 para que la renta per cápita en pesetas constantes de 1935 alcance los valores de este último año (Bahamonde y Martínez, 1999: 54-55; Velarde, 1995: 75). Un fenómeno económico al que se dedica cierta atención (aparece en cinco de los treinta y un artículos de temática político-económica, el 31 por ciento) es la inflación. En "Economía e inflación", Hispanicus explica que no es lo mismo la inflación y el alza de precios y que no se debe "encadenar la economía con el mito de la circulación" del dinero. Apunta a que esta inflación se debe a la crisis internacional y a los especuladores (Arriba, 29 de enero de 1947: 1). A éstos últimos dedica un duro artículo en el que los acusa de actuar bajo el signo liberal tanto en el terreno agrario como en el inmobiliario, y llama al gobierno a aprobar una nueva ley de Sociedades Anónimas ("Especuladores", Arriba, 31 de enero de 1947: 1).

Según Juan Velarde, Franco creía que el aumento del gasto público no conllevaba necesariamente inflación, "una idea absurda" a su juicio. Quería mantener alto el tipo de cambio, pero odiaba la inflación, y más tarde su régimen terminó aviniéndose a una devaluación de la peseta para contener este fenómeno.

Figura 4: Distribución de los artículos por seudónimo y año.

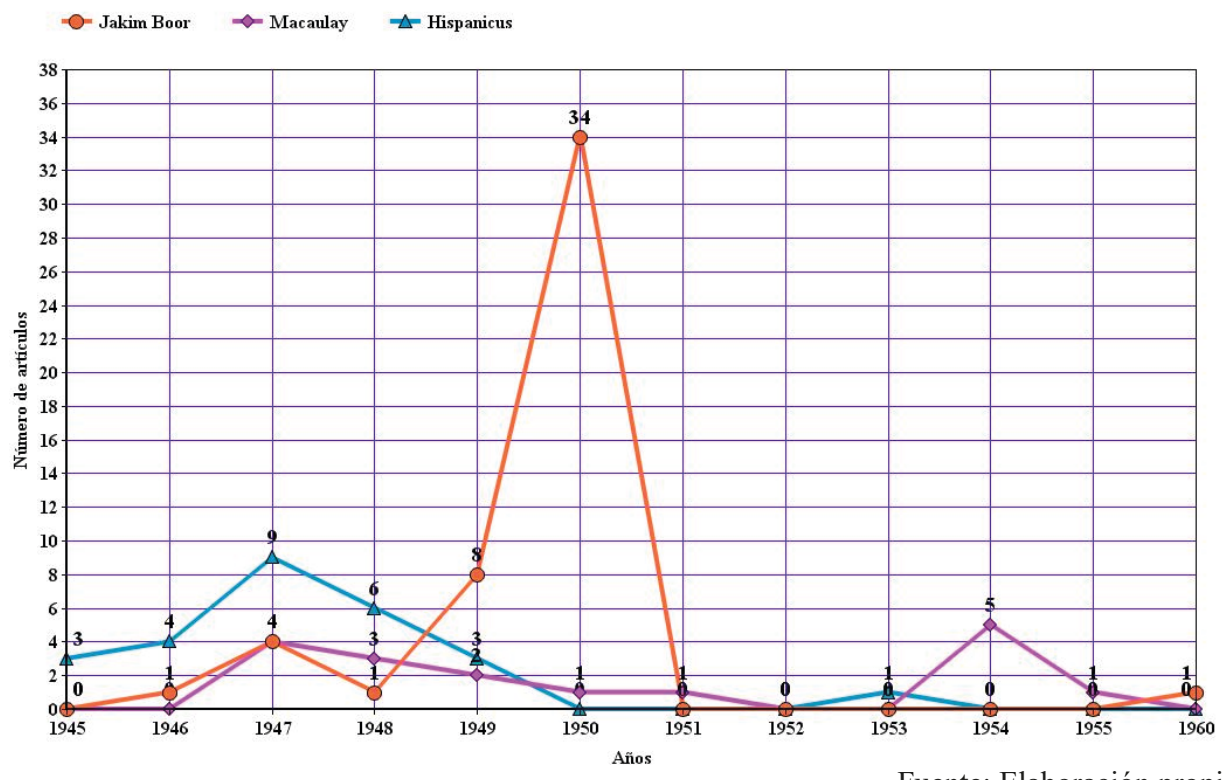

Fuente: Elaboración propia 
El nivel de vida de la población es otra preocupación presente en los artículos, con nueve entradas de treinta y una (el 29 por ciento de la categoría). La preocupación está plenamente fundamentada. "España era uno de los países más pobres y subdesarrollados de Europa (junto con Portugal y Grecia) y sus niveles de bienestar social y consumo público eran incluso inferiores a algunos países latinoamericanos" (Moradiellos, 2000: 114) Sin embargo, en "El hecho social" Franco argumentaba, de manera optimista, que lo político había dado paso a lo social y que para mejorar las condiciones de vida de la gente era preciso el intervencionismo en las empresas, opuesto tanto al liberalismo como al marxismo (Hispanicus, Arriba, 24 de diciembre de 1946: 1). Esta intervención, necesaria -según Hispanicus- para hacer frente la acción de los perniciosos especuladores que escapan a la acción del gobierno, explica Velarde que se concretaba en organismos como la Fiscalía de Tasas o la Comisaría de Abastecimientos y Transportes, empleados para paliar la escasez agravada por el aislamiento internacional ${ }^{28}$. Después del corporativismo inicial, eso sí, la economía española evoluciona hacia cierto liberalismo económico en la década de 1950 (Velarde, 1995: 74) y, consecuentemente, Franco deja de escribir sobre esta materia.

Fiel defensor de la política económica del gobierno, Hispanicus alude en cuatro ocasiones (un 13 por ciento de la categoría) a la falta de conocimiento del público en materia económica. Verbigracia, en "Un cuarto a espadas" afirma que durante la Dictadura -la de Primo de Rivera; la suya es el Régimen o la Revolución- los estudios en Economía fueron desatendidos y ello contribuye a la decadencia del país (Arriba, 12 de diciembre de1946: 1). Esta colaboración tiene la peculiaridad, no observada en ninguna otra, de ir precedida de un antetítulo: "Verdades españolas".

Franco aborda muy escasamente el mundo del trabajo, que aparece únicamente en tres artículos (el 9 por cierto de la categoría). El dictador se muestra muy conservador en este aspecto: rechaza la huelga y la acción directa, porque entiende que la huelga es la ley de la selva; propone en su lugar la solución judicial de los problemas laborales en conjunción con las leyes sociales y el Fuero de los españoles (Hispanicus, "Huelga, justicia y libertad", Arriba, 11 de diciembre de 1947: 1). Asimismo muestra cierta preocupación por la carestía que afecta al país y alaba la resistencia del pueblo español, al que apela al esfuerzo colectivo para solucionar la situación (Hispanicus, "Alerta", Arriba, 6 de diciembre de 1946: 1). El profesor Velarde apunta la hipótesis de que las preocupaciones de carácter social quizá le llegaron a Franco a través de uno de sus directores de ejercicios espirituales, el padre Llanos ${ }^{29}$, capellán de Arriba y después miembro de Comisiones Obreras ${ }^{30}$. Las condiciones de los trabajadores en esta época eran de una "rígida disciplina laboral y una drástica fijación de salarios" (García Delgado, 2008: 208); se estima que los salarios reales cayeron a lo largo de la década de 1940 un 50 por ciento (Bahamonde y Martínez, 1999: 55). 


\section{Críticas, alusiones y repercusión de los artículos periodísticos de Franco}

La mayor parte de la crítica historiográfica se muestra implacable con el objeto de estudio de este trabajo. Así, en la obra Todo Franco se dice que el escarceo de Franco con el periodismo "fue una continuación de su gestión política, ya que se concentró en criticar severamente la masonería, una de sus grandes obsesiones, y el liberalismo. Luego esos artículos los publicó en un libro titulado Masonería, que apareció en 1952. De esta manera, Franco confirmó que se puede escribir sin leer más que severos informes burocráticos. Otra cosa es escribir bien" (Bardavío y Sinova, 2000: 24).

Amando de Miguel, en su biografía del dictador escrita al año siguiente de su muerte, censura toda su obra: "Franco no fue lo que se dice un escritor original (si bien fue autor de un guion cinematográfico), ni un orador destacado (aunque por oficio hubiera de pronunciar miles de discursos), ni tan siquiera un tratadista conocido de temas militares (por más que fundara y dirigiera la Academia Militar de Zaragoza). Lo suyo no fue nunca articular conceptos, manejar ideas, sino mover peones en el tablero de ajedrez periodístico. Terminó por ser lo que siempre odió: un político profesional" (1976: 46).

Enrique de Aguinaga tampoco le otorga habilidad literaria al Caudillo. A su entender, "está en una retórica plana, directa, de pater familias. Franco era primario. Son unos artículos planos, de sentido común. No recuerdo que se comentasen" ${ }^{\prime 1}$.

Juan Pablo Fusi se muestra atónito ante Jakim Boor: "Masonería era un libro sorprendente, incomprensible. Lo era que un jefe de Estado de un país moderno, militar brillante y estadista cauteloso, tuviese una visión del mundo y de la política internacional basada en una formidable y obsesiva superchería: en la idea de que toda la historia contemporánea no era sino el resultado de una gigantesca conspiración masónica" (1995: 128-129).

Paul Preston, muy crítico en toda su biografía, le otorga no obstante cierta destreza literaria al hablar de Jakim Boor: "Los artículos estaban redactados en un estilo más desenvuelto que otros escritos y discursos contemporáneos del Caudillo. Se ha sugerido que el amigo de Franco y escritor Joaquín Arrarás le ayudó a elaborarlos, aunque el estilo podría reflejar la falta de inhibiciones que prestaba a Franco el uso del seudónimo" (2004: 614).

Sin concederle capacidad retórica, ya que "no resulta un autor de textos profundos, complejos, elaborados y sutiles", Enrique Moradiellos califica el estilo comunicativo de Franco como "eficaz. Simple y sencillo, maniqueo y efectista... No era ningún ignorante, ni como comandante de tropas a las que sabía arengar, ni como periodista ocasional. Tenía un conjunto de ideas simples y sencillas, muy firmemente asentadas, que utilizaba a conciencia en textos de estructura muy clara, lógica, muchas veces maniquea y falta de complejidad. Pero efectiva, me parece. Son conocidas sus frases cortas y secas para dar a conocer su opinión: orden, contraorden, desorden; un hombre es esclavo de lo que dice y dueño de lo que calla; yo jamás seré una reina madre. En los contextos donde se pronunciaban, esas sentencias parecían reflexiones 
filosóficas de hondura a los partidarios y simplezas a los adversarios. Pero todos comprendían su sentido" 32 .

Mucho más benevolente es la crítica publicada en $A B C$ sobre el libro de Masonería, en la que se dan por buenas y bien documentadas todas las elucubraciones de Boor sobre la acción masónica como causante de la decadencia del Imperio español. El académico Melchor Fernández Almagro alaba el patriotismo y la religiosidad del autor y afirma que los artículos más circunstanciales "adquieren un sentido orgánico" al unirse a los demás. Termina diciendo que "contra la amenaza de la masonería y del comunismo se alza $J$. Boor, con autorizada pluma, en este libro de claro juicio, animada prosa y firme dialéctica" ("Crítica y glosa. Masonería por J. Boor", ABC, 26 de junio de 1952: 15).

Asimismo es benévolo en su juicio Luis Suárez, cuyas palabras recalcan la continuidad en el estilo del dictador a la hora de escribir: "Los que he leído me parecen buenos; no diferentes del estilo empleado en los publicados ni en las revistas militares [la Revista de Tropas Coloniales]" ${ }^{\prime 33}$.

En cuanto a su repercusión, la prensa aludía de vez en cuando a los artículos de Franco. La Prensa del Movimiento solía copiar a Arriba e incluso la prensa privada reprodujo alguno de los artículos de relevancia internacional (Hispanicus, "Marruecos", $A B C, 15$ de septiembre de 1953: 22-23; Macaulay, "Gibraltar y la masonería", La Vanguardia Española, 5 de agosto de 1955: 1). El propio periódico donde se publicaban las colaboraciones también recogía la repercusión de las mismas fuera del país. Así, Arriba cita, no sin cierta ironía -dado que se trata de un enemigo del régimen- un extracto de la obra de Salvador de Madariaga España en la que se culpa al comunismo internacional de instigar la Guerra Civil ("Una adhesión al artículo de Hispanicus", 6 de noviembre de 1946). Más adelante, durante la serie de artículos de Macaulay sobre Gibraltar (1954), el corresponsal Guy Bueno informó de cómo los diarios londinenses publicaban extractos del cuarto de ellos, con titulares llamativos como "La paciencia de España está agotada" o "El caso de Gibraltar es grave" ("Los artículos de Macaulay sobre Gibraltar, en la prensa británica", Arriba, 16 de marzo de 1954: 1). En alguna ocasión, estas colaboraciones eran retransmitidas también por la radio (Hispanicus, "España es la que acusa", Arriba, 3 de noviembre de 1946: 1).

En cuanto a la oposición al régimen, Raanan Rein señala que "las fuerzas políticas antifranquistas lo usaban en su favor [el escarceo periodístico de Franco], como era de esperar. A los gobiernos/grupos/fuerzas políticas que tenían interés en colaborar con la España franquista, les convenía que estos textos no estuvieran firmados con el nombre del Caudillo, así que lo ignoraban"34.

Como revela la lectura de diversos documentos depositados en la Fundación Francisco Franco, Franco se mantenía informado de lo que se comentaba en el extranjero acerca de sus artículos a través del Ministerio de Asuntos Exteriores, especialmente gracias a la Oficina de Información Diplomática. Algunos de los comentarios mecanografiados son muy ilustrativos de cómo se percibían en el exterior las colaboraciones y cómo eran valoradas por la prensa internacional. Frente a la casi abulia que 
despiertan los artículos en los expertos españoles, para los periódicos extranjeros constituían ataques furibundos. Las notas diplomáticas proporcionan también claves para su entendimiento e interpretación. En la Fundación también se conservan unas pocas cartas de lectores entusiasmados de los artículos.

El 15 de noviembre de 1948 un ministro -no determinado por el documentode viaje en Oslo envía a Madrid un telegrama: "Diarios comentan artículo Arriba domingo [se trata de "En el fango", publicado el día anterior], que según dicen ataca Gran Bretaña y Secretario General ONU, firmado por seudónimo, que diarios afirman se dice que es el empleado en artículos escritos por propio Generalísimo". Debajo del texto mecanografiado aparece manuscrita la palabra Macaulay entre paréntesis, seguido de "lo hemos traducido al inglés y se envió a [nombre propio que empieza por $\mathrm{M}$, ininteligible] donde parece que ha interesado mucho: se reparte también en París [continúa garabato ilegible] ${ }^{35}$.

Alan Walker, corresponsal del Daily Telegraph -en el margen aparece anotado a mano "católico y enemigo de España"-, escribe unas "Observaciones sobre ciertos puntos del artículo sobre la francmasonería de Jakim Boor aparecido en el número de Arriba de 16 de febrero de 1949" [se trata de "Los que no perdonan"] ${ }^{36}$, fechadas el 24 de febrero de 1949 en Madrid en una carta cuyo destinatario es desconocido. El documento respalda la idea conspiranoica de Franco, llegando incluso a decir que "la francmasonería ha sido durante mucho tiempo y sigue siendo (como dijo Dostoievski de los judíos) una influencia desintegrante en la política mundial". Por otra parte, Walker realiza varias matizaciones de gran interés a ciertos argumentos exagerados de Boor. La primera de ellas que es imposible que haya seis millones de masones en Escocia, cuando la población no llegaba ni siquiera a cinco millones de almas. Tampoco pueden existir nueve millones de masones en la Gran Logia de Inglaterra "ya que, de ser este el caso, la entera población masculina estaría formada por Masones". La carta, conservada con subrayados, prosigue esbozando las posibles relaciones de la masonería inglesa con otras ramas de la organización.

En diciembre de 1949 hay diversas informaciones de agencias. La entrada del día 5 refiere una información del moderadamente indignado The Times: "Bajo el título de 'Albión' y con el seudónimo Macaulay, el cual se cree oculta un oscuro personaje quien se esconde bajo el nombre de Hispanicus y que se halla muy relacionado con las esferas oficiales más altas, el periódico Arriba consagra en el 57 aniversario de Franco la mitad de su primera página al más violento y extenso editorial contra Inglaterra que haya publicado ningún periódico falangista o haya sido radiado desde que Hitler perdió la guerra" 37 .

La diplomacia recoge una interesante información del New York Times -periódico al que Franco calificó en una ocasión como "baluarte de la masonería internacional" (Franco Salgado, 1976: 255) - fechada el 18 de diciembre sobre España ${ }^{38}$ : "Existe un evidente y creciente resentimiento en los círculos oficiales sobre la negativa de las Naciones Unidas a cambiar su actitud. España no quiere embajadores a menos de estar segura de su buena fe, así se expresa el periódico del partido de Falange Arriba 
en un editorial que se publica en primera plana y en el que ataca la política británica y en menor grado la de Estados Unidos [se trata de "Dialéctica fácil", aparecido ese mismo día]. Bajo la firma de Macaulay -cuya identidad nunca ha sido rebelada [sic] pero se rumorea ser el mismo Caudillo o alguien inspirado directamente por él- este editorial es todavía más fuerte y violento que el editorial publicado hace una semana". Tras un resumen del artículo, la Dama Gris menosprecia su importancia: "Estas declaraciones del periódico Arriba no tienen importancia en cuanto se refieren a su influencia en la opinión pública, pues solamente tiene una tirada de unos pocos miles de ejemplares, pero es importante en cuanto reflejan el pensamiento y el deseo de los gobernantes españoles y lo que ellos quieren divulgar". Al lado de este último párrafo está anotado a mano: "En vista de ello se pide a otros diarios que lo reproduzcan" y una inicial como firma que se asemeja a una A. Ese mismo día, la agencia United Press reproduce parte del texto de Macaulay y, sin glosarlo, "señala que la persona que se esconde tras el seudónimo de Macaulay puede ser Franco o un colaborador íntimo"39.

Otra nota de la Oficina de Información Diplomática -fechada el 23 de abril de 1950- recoge una larga crónica del Christian Science Monitor en la que se comentan los artículos de Jakim Boor atacando a la masonería. "Lo que intriga a los observadores extranjeros es el por qué la España de Franco provoca la enemistad con una organización de tanta influencia como la masonería", se lee en subrayado ${ }^{40}$. Este debate ha sido contextualizado por Luis Suárez en el marco de la relación entre la masonería, la religión católica y el franquismo: "Si en el caso del protestantismo se ve con claridad que el deseo del gobierno se orientaba hacia mayores concesiones, siendo frenado por los obispos y, en definitiva, también por las leyes de la Iglesia, en el de la masonería la oposición radical partía del propio Franco. El 27 de marzo de 1950, el New York Times dio la noticia de que la nueva serie de artículos firmados por Jakim Boor en Arriba constituían la intención de su autor, pero constituye una hipótesis plausible que se tratara más bien de una reacción a lo que estaba sucediendo en Argentina y a la resistencia denodada de Truman al establecimiento de relaciones con España, cuestiones ambas aparentemente ligadas al poder de la masonería en ambos países". A su entender, hay que "admitir, como un hecho fuera de toda duda, que el Generalísimo veía en la masonería un enemigo con el que no cabía ningún entendimiento" (2005: 389-390).

El último despacho consultado no tiene fecha; la Fundación Franco lo data sin seguridad en 1951. En ella se informa que el director de A Voz de Lisboa, Pedro Correia Marqués, había mencionado en un editorial un artículo de $J$. Boor. En dicho editorial se congratulaba de la libertad y el orden que reinan en una España que ha rechazado a las logias y ha superado los problemas económicos creados por masones y comunistas mezclados ${ }^{41}$.

Así pues, en cuanto a la posible repercusión de los artículos de Franco hay que trabajar con indicios. Moradiellos aventura que sí calaron, pero él mismo reconoce que es imposible saberlo con seguridad: "Fueron bastante comentados y divulgados. Y creo que llegó a saberse de facto que su autor era Franco, sin mucho problema. 
Quizá se quiso que así fuera, por vía oficiosa y no oficial. Pero no tengo ningún documento probatorio" 42 .

En la última etapa de las colaboraciones -que como se ha visto se centraron monotemáticamente en Gibraltar-, la paciencia inglesa se agotó, de acuerdo con Miguel Ángel Criado, "el artículo de Macaulay [del 15 de mayo de 1954] tiene un gran impacto entre los británicos. El 20 de mayo tres destacados miembros del Partido Laborista interpelan a Churchill en el Parlamento. Quieren que el primer ministro aclare qué promesas hizo a España en relación con Gibraltar si se mantenía en la Guerra. Churchill rechaza que existiera compromiso alguno". El periodista prosigue señalando que las acusaciones de Franco en sus artículos eran falsas, pues el ex premier británico nunca prometió al Caudillo que Inglaterra abandonaría el Peñón. "Lo cierto es que la desclasificación en 2005 de una serie de documentos de los archivos nacionales británicos viene a contradecir las acusaciones españolas en 1954: Churchill nunca prometió devolver la Roca" (2006: 21 y 23).

Pero, sin duda alguna, la historia más curiosa del general como escritor secreto es que la censura se atrevió a tacharle con lápiz rojo un artículo (Macaulay, "Serenidad", Arriba, 26 de agosto de 1947: 1) (Rodríguez, 1982: 7). El documento, en el que el autor hace una particular defensa de los laboristas británicos -nada favorables al franquismo-, recibió del censor dos gruesas tachaduras en el párrafo en el que se defendía a los ingleses y en otro en el que se mencionaba el sistema de consignas de la prensa española. El funcionario nocturno no sabía quién se ocultaba detrás de Macaulay (Aguinaga, 2002: 16-17). Aguinaga, el corrector de la galerada -la cual conserva- recuerda que en la redacción "todos se rieron a mandíbula batiente cuando volvió marcada con rojo de Monte Esquinza (la oficina de la censura) y naturalmente se publicó tal y como el Caudillo la había enviado"43.

\section{Conclusiones}

Llegado el momento de finalizar y extraer conclusiones del trabajo empírico realizado, se vuelve aquí a las hipótesis para comprobar si efectivamente son válidas o han quedado rechazadas.

Primera. El Generalísimo creía que judíos, masones y comunistas eran una amenaza grave para España y dedicó numerosas líneas a combatirlos. Cierto, como han demostrado las afirmaciones de numerosos historiadores y el análisis de contenido: de los artículos dedicados a los enemigos (60 de 91), estos acumulan 83 de las 141 menciones de las distintas variables (un 58 por ciento).

Segunda. Los artículos se redactaron de manera muy discreta, casi secreta. Cierto. Según unas fuentes, se puede afirmar que cuando se publicaron los artículos muy pocas personas sabían con certeza -aunque algunos más podían sospecharlo- que Franco estaba detrás de ellos, mientras que hasta después de la muerte del dictador y la reedición de Masonería no fue público que él era Jakim Boor. Otras, en cambio, 
apuntan que en la calle sí se sabía, pero ante la falta de pruebas documentales y de testimonios de población no experta, cabe dar validez a la hipótesis.

Tercera. El Caudillo dejó de escribir finalizada la etapa de aislamiento internacional de España. Cierto. El último artículo -salvando el de 1960, que aparece fuera de contexto- corresponde a 1955, año de entrada de España en la ONU.

Cuarta. Franco se situaba en la cúspide del sistema informativo. Cierto. La prensa del período 1945-1960 estaba totalmente subordinada al Estado del que él era Jefe indiscutido y todopoderoso, pues no estaba sujeto a ninguna limitación: así, se hizo caso omiso de la censura que pretendía tachar uno de sus artículos, que el dictador publicó en el periódico de su elección.

Quinta. Elaboró sus opiniones periodísticas él solo. No es posible aquí ser concluyente, porque las distintas fuentes se contradicen. Solamente es viable afirmar, a la vista de las pruebas documentales, que Franco no solamente se limitaba a firmar los guiones de sus colaboraciones, sino que tachaba y añadía palabras.

Sexta. Sus contribuciones aparecieron en el diario Arriba, en una posición poco llamativa. Falso. Los artículos aparecieron la inmensa mayoría de las ocasiones en la portada del periódico.

Séptima. Franco escribía por puro entretenimiento. Aunque es imposible determinarlo al cien por cien, caba suponer que sí, dado que previamente había escrito dos novelas y era aficionado en su juventud a publicar artículos en revistas militares.

Octava. Las colaboraciones provocaron algunos incidentes diplomáticos. Falso. Ante la evidencia de la historia, no dañaron las relaciones internacionales de España más allá de la situación de aislamiento y condena internacional en que ya se encontraba el régimen; no motivaron tampoco ninguna reacción directa contra el autor o contra España.

Novena. Los artículos de Franco estaban fuertemente condicionados por sus experiencias vitales y son similares a su obra literaria anterior. Cierto. El estilo literario es similar y muchos de los temas que aparecen en ellos (Marruecos, la masonería, el comunismo...) ya estaban presentes en sus lecturas, en sus obras y en su pensamiento de juventud.

Décima. Franco trataba temas de actualidad. Parcialmente cierto. Ocasionalmente lo hacía, pero la historia está muy presente en gran parte de ellos, tanto la de la masonería en la categoría de Enemigos, como la política y social en la categoría de Política, Economía y Sociedad con 14 de las 73 menciones de las distintas variables (el 19 por ciento).

Finalmente, hay que subrayar que las cuestiones de tipo más íntimo y emocional (el por qué en última instancia de esas colaboraciones periodísticas) y de efecto (qué alcance efectivo tuvieron) no han podido ser resueltas de una manera incontrovertible. 


\section{Referencias bibliográficas}

AGUINAGA, Enrique de (2002): "De cómo la censura franquista tachó un artículo de Franco". En $A P M$, núm. 43, pp. 16-17.

(2010): Aqui hubo una guerra. Madrid, Plataforma 2003.

ANDER-EGG, Ezequiel (1997): Técnicas de investigación social. México D.F., El Ateneo.

BAHAMONDE, Ángel y MARTÍNEZ, Jesús (1999): "La construcción de la dictadura (1939-1959)". En MARTíNEZ, Jesús Antonio et al.: Historia de España siglo XX. 1939-1996. Madrid, Cátedra.

BARDAVÍO, Joaquín y SINOVA, Justino (2000): Todo Franco. Franquismo y antifranquismo de la A a la Z. Barcelona, Plaza y Janés.

BARRERA, Carlos (1995): Periodismo y franquismo. De la censura a la apertura. Barcelona, Ediciones Internacionales Universitarias.

BENNASAR, Bartolomé (1996): Franco. Madrid, Edaf.

BOOR, Jakim [seudónimo de FRANCO BAHAMONDE, Francisco] (1952): Masonería. Madrid, Gráficas Valera.

CHULIÁ, Elisa (1997): La evolución silenciosa de las dictaduras. El régimen de Franco ante la prensa y el periodismo [tesis doctoral]. Madrid, Instituto Juan March de Estudios e Investigaciones.

(2001): El poder y la palabra. Prensa y poder político en las dictaduras. El régimen de Franco ante la prensa y el periodismo. Madrid, Biblioteca Nueva.

CORBETTA, Piergiorgio (2007): Metodología y técnicas de investigación social. Madrid, McGraw-Hill.

CRIADO, Miguel Ángel (2006): "La batalla de la roca". En LAVIANA, Juan Carlos (Coord.): 1954. Un grito unánime: ; Gibraltar, español! Colección El franquismo año a año. Lo que se contaba y ocultaba durante la dictadura, vol. 14. Madrid, Unidad Editorial.

DE LA CIERVA, Ricardo (1976a): Historia del franquismo. Orígenes y configuración (1939-1945). Barcelona, Planeta

(Dir.) (1976b): Vida de Franco. Serie de 52 capítulos coleccionables. Madrid, Prensa Española.

(1979): Historia del franquismo. Aislamiento, transformación, agonía (19451975). Barcelona, Planeta.

DE MIGUEL RODRÍGUEZ, Amando (1976): Franco, Franco, Franco. Madrid, Ediciones 99.

DÍAZ-PLAJA, Fernando (1997): Anecdotario de la España franquista. Barcelona, Plaza \& Janés.

DOMÍNGUEZ ARRIBAS, Javier (2009): El enemigo judeo masónico en la propaganda franquista, 1936-1945. Madrid, Marcial Pons. [Edición de la Tesis doctoral, presentada en la EHESS de París en 2006, con el título de L'ennemi judéo-masonique dans la propagande franquiste, 1936-1945].

DUARTE, Ángel; VEIGA, Francisco y UCELAY DA CAL, Enric (2006): La paz simulada. Una historia de la Guerra Fría. Madrid, Alianza Editorial. 
FERNÁNDEZ SANTANDER, Carlos (2005): El general Franco. Un dictador en un tiempo de infamia. Barcelona, Crítica.

FERRER BENIMELI, José Antonio (1977): "Franco contra la masonería". En Historia 16 , núm. 15 , pp. 37-51.

(1982): El contubernio judeo-masónico-comunista. Madrid, Istmo.

FRANCO SALGADO-ARAUJO, Francisco (1976): Mis conversaciones privadas con Franco. Barcelona, Planeta.

(1977): Mi vida junto a Franco. Barcelona, Planeta.

FUENTES, Juan Francisco y FERNÁNDEZ SEBASTIÁN, Javier (1998): Historia del Periodismo español: prensa, política y opinión pública en la España contemporánea. Madrid, Síntesis.

FUSI, Juan Pablo (1995): Franco, autoritarismo y poder personal. Madrid, Taurus. "La cultura". En GARCÍA DELGADO, José Luis (2000): Franquismo: el juicio de la historia. Madrid, Temas de hoy.

GARCÍA GALERA, María del Carmen y BERGANZA CONDE, María Rosa (2005): "El método científico aplicado a la investigación en Comunicación Mediática". En BERGANZA CONDE, María Rosa et al.: Investigar en Comunicación. Guía práctica de métodos y técnicas de investigación social en Comunicación. Madrid, McGraw-Hill.

GARCÍA DELGADO, José Luis (2008): "De la autarquía a la crisis del petróleo". En GARCÍA DE CORTÁZAR, Fernando (Dir.): La Historia de España en su lugar. Tomo 10: De la Guerra Civil al siglo XXI (desde 1936 hasta hoy). Barcelona, Planeta.

GARCÍA GALINDO, Juan Antonio (Ed.) (2002): La comunicación social durante el franquismo. Málaga, CEDMA. [Actas IV Congreso de la AHC, 814 págs.]

GIMÉNEZ CABALLERO, Ernesto (1979): Memorias de un dictador. Barcelona, Planeta.

GOLDHAGEN, Daniel (1997). Los verdugos voluntarios de Hitler. Los alemanes corrientes y el Holocausto. Madrid, Taurus.

GOMIS, Lorenzo (1991): Teoría del Periodismo. Barcelona, Paidós.

GONZÁLEZ, Isidro (2009): Los judios y la Guerra Civil española, Madrid, Hebraica Ediciones.

GONZÁLEZ, Nazario (1995): “La cultura en la España de Franco". En ANDRÉSGALLEGO, José et al.: Historia de España. España actual. España y el mundo (1939-1975). Madrid, Gredos.

HISPANICUS [seudónimo de FRANCO BAHAMONDE, Francisco] (1964): Hispanicus. Selección de artículos publicados en "Arriba". Madrid [sin consignación de la editorial, recopilación del propio periódico].

JEREZ RIESCO, José Luis: Prólogo a BOOR, Jakim (2003): Masonería. Madrid, Ojeda.

LÓPEZ-ARANGUREN, Eduardo (2007): "Análisis de contenido". En GARCÍA FERRANDO, Manuel: El análisis de la realidad social: métodos y técnicas de investigación. Madrid, Alianza. 
LÓPEZ DE ZUAZO ALGAR, Antonio (1981): Catálogo de periodistas españoles del siglo XX. Volumen I: A-F. Madrid, Fundación Universidad-Empresa.

(1990): Diccionario del Periodismo. Madrid, Ediciones Pirámide.

(2008): Diccionario de seudónimos periodísticos españoles del siglo XX. Madrid, Fragua.

MARTÍNEZ, Jesús Antonio (1999): "La consolidación de la dictadura (1951-1959)". En MARTíNEZ, Jesús Antonio et al.: Historia de España siglo XX. 1939-1996. Madrid, Cátedra.

MATOS, Helena (2003): Salazar. Vol. 1, A construção do mito. Vol. 2, A Propaganda. Lisboa, Círculo de Leitores.

MORADIELLOS, Enrique (2000): La España de Franco (1939-1975). Política y Sociedad. Madrid, Síntesis.

MORALES RUIZ, Juan José (2004): “Alusiones antisemitas en el libro Masonería de Francisco Franco (Jakin Boor)". En FERRER BENIMELI (Dir.): La masonería en Madrid y en España del siglo XVIII al XXI. Tomo II. Zaragoza, Centro de Estudios Históricos de la Masonería Española.

NIÑO, Antonio y MONTERO, José Antonio (Eds.) (2012): Guerra Fría y propaganda. Estados Unidos y su cruzada cultural en Europa y América Latina. Madrid, Biblioteca Nueva.

PALACIOS, Jesús y PAYNE, Stanley George (2008): Franco, mi padre. Memorias de Carmen Franco, la hija del Caudillo. Madrid, La Esfera de los Libros.

PAYNE, Stanley George (1987): El régimen de Franco 1936-1975. Madrid, Alianza Editorial.

(2008): "El general Franco". En GARCÍA DE CORTÁZAR, Fernando (Dir.): $L a$ Historia de España en su lugar. Tomo 8: De la Restauración a la $2^{a}$ República (1874-936). Barcelona, Planeta.

PENA RODRÍGUEZ, Alberto (2008): "La creación de la imagen del franquismo en el Portugal salazarista". En REIS TORGAL, Luis y PAULO, Eloisa (Coords.): Estados autoritarios e totalitarios e suas representaçoes. Coimbra, Universidade. (2013): "Salazar y Franco en el panorama internacional: estrategia diplomática y propaganda (1936-1945)". En Espacio, Tiempo y Forma, núm. 23, Serie V, Historia Contemporánea, t. 25, págs. 23-48.

PÉREZ, Joseph (2005): Los judios en España. Madrid, Marcial Pons.

PIZARROSO, Alejandro (1989): "Política informativa. Información y propaganda, 1939-1966". En ÁLVAREZ, Jesús Timoteo et al. Historia de los medios de comunicación en España. Periodismo, imagen y publicidad, 1900-1990. Barcelona, Ariel, págs. 231-249.

(1999): "La Historia de la Propaganda: una aproximación metodológica". En Historia y Comunicación Social, núm. 4, págs. 145-171.

(2002): "Italia y España franquista información y propaganda (1939-1945)". En GARCÍA GALINDO, Juan Antonio (ed.): La comunicación social durante el franquismo. Málaga, CEDMA, págs. 33-54.

PRESTON, Paul (2004): Franco 'Caudillo de España'. Barcelona, De Bolsillo. 
REES, Laurence (2013). El oscuro carisma de Hitler. Cómo y porqué arrastró a millones al abismo. Barcelona, Crítica.

REIG TAPIA, Alberto (2005): Franco: el César Superlativo. Madrid, Tecnos.

RODRÍGUEZ, Pepe (2006): Masonería al descubierto. Del mito a la realidad (11002006). Madrid, Temas de hoy.

SÁNCHEZ ARANDA, José Javier (2005): "Análisis de contenido cuantitativo de medios". En BERGANZA CONDE, María Rosa et al.: Investigar en Comunicación. Guía práctica de métodos y técnicas de investigación social en Comunicación. Madrid, McGraw-Hill y BARRERA DEL BARRIO, Carlos (1992): Historia del periodismo español desde sus orígenes hasta 1975. Pamplona, Universidad de Navarra.

SELVA, Enrique (2000): Ernesto Giménez Caballero. Entre la vanguardia y el fascismo. Valencia, Pre-textos.

SEOANE, María CRUZ y SAIZ, María Dolores (2007): Cuatro siglos de Periodismo en España. De los avisos a los periódicos digitales. Madrid, Alianza.

SERRANO SUÑER, Ramón (2007): Entre el silencio y la propaganda, la Historia como fue. Memorias. Barcelona, Planeta.

SEVILLANO CALERO, Francisco (1997): "La estructura de la prensa diaria en España durante el franquismo". En Investigaciones históricas: Epoca moderna y contemporánea, núm. 17, págs. 315-340.

SINOVA, Justino (2006): La censura de prensa durante el franquismo. Barcelona, De Bolsillo.

SUÁREZ FERNÁNDEZ, Luis (1984): Francisco Franco y su tiempo. Volumen IV. Madrid, Fundación Nacional Francisco Franco. (2005): Franco. Barcelona, Ariel.

TUSELL, Javier (1984): Franco y los católicos. La política interior española entre 1945 y 1947. Madrid, Alianza.

(1993): Carrero. La eminencia gris del régimen de Franco. Madrid, Temas de hoy.

(1996): La dictadura de Franco. Madrid, Alianza.

UTRERA MOLINA, José (2000): "Recuerdos de Franco". En Razón Española, núm. 104, pp. 349-360.

VALLES, Miguel S. (2002): "Entrevistas cualitativas". En Cuadernos Metodológicos, núm. 32, Madrid, Centro de Investigaciones Sociológicas.

VELARDE, Juan (1995): “De la economía de guerra a la Transición”. En ANDRÉSGALLEGO, José et al.: Historia de España. España actual. España y el mundo (1939-1975). Madrid, Gredos.

ZENOBI, Laura (2011): La construcción del mito de Franco. Madrid, Cátedra. 


\subsection{Fuentes y archivos consultados}

\subsubsection{Fuentes orales}

Aguinaga López, Enrique de (Valverde del Fresno, Cáceres, 1923): periodista que trabajó en el periódico Arriba (1945-1966) y catedrático jubilado de Periodismo de la Universidad Complutense de Madrid. Entrevistas realizadas en Madrid el 12 de diciembre de 2013, 17 de enero de 2014 y 28 de febrero de 2014.

Gibello, Antonio (Madrid, 1932): periodista, redactor de Arriba entre 1957 y 1968, ex redactor jefe de la agencia Pyresa y director de El Alcázar entre 1971 y 1977. Entrevista realizada en Madrid el 4 de junio de 2014.

Martínez Hernando, Bernardino (Mansilla de las Mulas, León, 1934): bibliotecario de la Asociación de la Prensa de Madrid y profesor jubilado de Periodismo de la Universidad Complutense de Madrid. Entrevista realizada en Madrid el 28 de abril de 2014.

Moradiellos García, Enrique (Oviedo, 1961): Catedrático de Historia Contemporánea en la Universidad de Extremadura. Entrevista realizada mediante correo electrónico, respondida el 23 de mayo de 2014.

Núñez Díaz-Balart, Mirta: profesora titular de Historia de la Comunicación Social en la Universidad Complutense de Madrid. Entrevista realizada en Madrid el 30 de abril de 2014.

Rein, Raanan (Givataim, Israel, 1960): profesor de Historia de Latinoamérica y Vice President en la Universidad de Tel Aviv. Entrevista realizada mediante correo electrónico, respondida el 13 de junio de 2014

Velarde Fuertes, Juan (Salas, Asturias, 1927): ex colaborador de Arriba (1952-1979), y catedrático emérito de Economía Aplicada en la Universidad Complutense de Madrid. Entrevista realizada por teléfono el 31 de mayo de 2014.

\subsubsection{Correspondencia}

Suárez Fernández, Luis (Gijón, 1924): historiador originalmente medievalista, biógrafo de Franco. Testimonio escrito en carta con matasellos del 30 de mayo de 2014.

\subsubsection{Archivos y Centros documentales públicos y privados}

Archivo de la agencia EFE.

Archivo personal de Enrique de Aguinaga (AEA).

Archivo de la Fundación Nacional Francisco Franco (AFNFF).

Biblioteca Nacional de España (BNE).

Biblioteca de la Universidad de Navarra.

Hemeroteca Municipal de Madrid (HMM) 


\section{9. Índice general de los artículos de Franco}

\begin{tabular}{|c|c|c|c|c|}
\hline Seudónimo & Nombre del artículo & Día & Mes & Año \\
\hline Hispanicus & Política clara & 9 & Marzo & 1945 \\
\hline Hispanicus & Comentario al sindicalismo internacional & 19 & Marzo & 1945 \\
\hline Hispanicus & La crisis del comunismo & 22 & Marzo & 1945 \\
\hline Hispanicus & ¡España es la que acusa! & 3 & Noviembre & 1946 \\
\hline Hispanicus & Alerta & 6 & Diciembre & 1946 \\
\hline Jakim Boor & Masonería y comunismo & 14 & Diciembre & 1946 \\
\hline Hispanicus & Un cuarto a espadas & 12 & Diciembre & 1946 \\
\hline Hispanicus & El hecho social & 24 & Diciembre & 1946 \\
\hline Jakim Boor & Política internacional & 4 & Enero & 1947 \\
\hline Jakim Boor & ¿Democracia? & 5 & Enero & 1947 \\
\hline Hispanicus & Sistemas políticos & 14 & Enero & 1947 \\
\hline Hispanicus & Nuestra revolución & 15 & Enero & 1947 \\
\hline Hispanicus & Economía e inflación & 29 & Enero & 1947 \\
\hline Hispanicus & Meditación & 30 & Enero & 1947 \\
\hline Hispanicus & Especuladores & 31 & Enero & 1947 \\
\hline Hispanicus & Lo político, lo económico y lo social & 1 & Febrero & 1947 \\
\hline Jakim Boor & La masonería, signo liberal & 5 & Febrero & 1947 \\
\hline Macaulay & "Memento" & 6 & Febrero & 1947 \\
\hline Hispanicus & El progreso económico & 9 & Febrero & 1947 \\
\hline Macaulay & Rectificación necesaria & 28 & Febrero & 1947 \\
\hline Jakim Boor & Tradiciones masónicas & 1 & Marzo & 1947 \\
\hline Macaulay & Comentario & 2 & Marzo & 1947 \\
\hline Hispanicus & Errores económicos & 9 & Marzo & 1947 \\
\hline Macaulay & Serenidad & 26 & Agosto & 1947 \\
\hline Hispanicus & Huelga, justicia y libertad & 11 & Diciembre & 1947 \\
\hline Hispanicus & Actualidad & 28 & Enero & 1948 \\
\hline Hispanicus & Ante el comunismo una política & 13 & Febrero & 1948 \\
\hline Hispanicus & Ante el comunismo la situación & 15 & Febrero & 1948 \\
\hline Hispanicus & Posiciones claras & 10 & Marzo & 1948 \\
\hline Hispanicus & Único camino & 21 & Marzo & 1948 \\
\hline Jakim Boor & El gran secreto & 4 & Abril & 1948 \\
\hline Hispanicus & El mal que nos hacen & 13 & Abril & 1948 \\
\hline Macaulay & Constancia & 18 & Abril & 1948 \\
\hline Macaulay & "La malquerida" & 9 & Julio & 1948 \\
\hline
\end{tabular}




\begin{tabular}{|c|c|c|c|c|}
\hline Macaulay & En el fango & 14 & Noviembre & 1948 \\
\hline Jakim Boor & Los que no perdonan & 16 & Febrero & 1949 \\
\hline Hispanicus & Socialismo y comunismo & 18 & Febrero & 1949 \\
\hline Jakim Boor & Un secreto desvelado & 2 & Marzo & 1949 \\
\hline Hispanicus & Dilema & 25 & Junio & 1949 \\
\hline Hispanicus & Realismo & 15 & Julio & 1949 \\
\hline Jakim Boor & El gran odio & 16 & Julio & 1949 \\
\hline Jakim Boor & El gran fraude democrático & 6 & Agosto & 1949 \\
\hline Jakim Boor & Alta masonería & 9 & Agosto & 1949 \\
\hline Jakim Boor & Bajo la dictadura masónica & 19 & Agosto & 1949 \\
\hline Jakim Boor & Conspiraciones masónicas & 31 & Agosto & 1949 \\
\hline Macaulay & Albión & 4 & Diciembre & 1949 \\
\hline Jakim Boor & Masonería & 11 & Diciembre & 1949 \\
\hline Macaulay & Dialéctica fácil & 18 & Diciembre & 1949 \\
\hline Jakim Boor & Una frase lapidaria & 12 & Febrero & 1950 \\
\hline Macaulay & Servicios secretos & 19 & Febrero & 1950 \\
\hline Jakim Boor & Enemigos eternos & 22 & Febrero & 1950 \\
\hline Jakim Boor & Crímenes de las logias & 19 & Marzo & 1950 \\
\hline Jakim Boor & Grados y pruebas & 26 & Marzo & 1950 \\
\hline Jakim Boor & Historia masónica & 2 & Abril & 1950 \\
\hline Jakim Boor & Persecuciones religiosas & 9 & Abril & 1950 \\
\hline Jakim Boor & Masonería anticatólica & 16 & Abril & 1950 \\
\hline Jakim Boor & Las logias son políticas & 23 & Abril & 1950 \\
\hline Jakim Boor & Maquinaciones bélicas & 30 & Abril & 1950 \\
\hline Jakim Boor & Internacionalismo & 17 & Mayo & 1950 \\
\hline Jakim Boor & Asociaciones y congresos & 21 & Mayo & 1950 \\
\hline Jakim Boor & La diplomacia del triángulo & 28 & Mayo & 1950 \\
\hline Jakim Boor & La "ferrerada" & 4 & Junio & 1950 \\
\hline Jakim Boor & Conspiraciones antiespañolas & 11 & Junio & 1950 \\
\hline Jakim Boor & Masonería española & 18 & Junio & 1950 \\
\hline Jakim Boor & Las grandes conjuras & 25 & Junio & 1950 \\
\hline Jakim Boor & Aclaración a un artículo & 27 & Junio & 1950 \\
\hline Jakim Boor & De Yalta a Potsdam & 2 & Julio & 1950 \\
\hline Jakim Boor & Maniobras masónicas & 9 & Julio & 1950 \\
\hline Jakim Boor & Acciones asesinas & 16 & Julio & 1950 \\
\hline Jakim Boor & Daños a España & 23 & Julio & 1950 \\
\hline Jakim Boor & Filosofía masónica & 30 & Julio & 1950 \\
\hline
\end{tabular}




\begin{tabular}{|l|l|l|l|l|}
\hline Jakim Boor & Batallas políticas & 6 & Agosto & 1950 \\
\hline Jakim Boor & Revolucionarismo y ateísmo & 13 & Agosto & 1950 \\
\hline Jakim Boor & Un decreto antimasónico & 20 & Agosto & 1950 \\
\hline Jakim Boor & El motín de Esquilache & 27 & Agosto & 1950 \\
\hline Jakim Boor & Infiltración masónica & 3 & Septiembre & 1950 \\
\hline Jakim Boor & Contra la Compañía de Jesús & 10 & Septiembre & 1950 \\
\hline Jakim Boor & Actividades en Francia & 17 & Septiembre & 1950 \\
\hline Jakim Boor & Crímenes & 24 & Septiembre & 1950 \\
\hline Jakim Boor & Campaña antijesuita & 1 & Octubre & 1950 \\
\hline Jakim Boor & Política y traición & 8 & Octubre & 1950 \\
\hline Jakim Boor & "La causa de El Escorial" & 22 & Octubre & 1950 \\
\hline Jakim Boor & La masonería, contra el ejército & 5 & Noviembre & 1950 \\
\hline Jakim Boor & La masonería actual & 3 & Mayo & 1951 \\
\hline Hispanicus & Marruecos & 13 & Septiembre & 1953 \\
\hline Macaulay & Siempre Gibraltar & 21 & Febrero & 1954 \\
\hline Macaulay & Ocaso de Gibraltar & 28 & Febrero & 1954 \\
\hline Macaulay & Visita inconveniente & 7 & Marzo & 1954 \\
\hline Macaulay & El único camino & 14 & Marzo & 1954 \\
\hline Macaulay & Comentario & 16 & Mayo & 1954 \\
\hline Macaulay & Gibraltar y la masonería & 27 & Marzo & 1960 \\
\hline Jakim Boor & La masonería no descansa & & 1955 \\
\hline
\end{tabular}

\section{Notas}

1 Información obtenida en entrevista a Juan Velarde, 31 de mayo de 2014.

2 Entrevista, 31 de mayo de 2014.

3 Entrevista, 28 de febrero de 2014.

4 José Ibáñez Martín, ministro entre 1939 y 1951. Después las competencias de Prensa pasaron al Ministerio de Información y Turismo, con Gabriel Arias Salgado ocupando la cartera entre 1951 y 1962.

5 Este dato y los siguientes provienen de entrevista realizada el 13 de diciembre de 2013.

6 Entrevista, 4 de junio de 2014.

7 Teoría general del empleo, el interés y el dinero (1936), considerada la magnum opus del economista británico, en la que expone las máximas de su pensamiento económico, favorable al aumento del gasto público en situaciones de recesión económica.

8 Entrevista, 31 de mayo de 2014. 
9 Thomas Babington, barón de Macaulay (1800-1859) escritor y político inglés de tendencia liberal (whig).

10 Manuel Lozano Sevilla fue miembro del Gabinete de Prensa de la Casa de S.E. el Generalísimo, del que llegó a ser jefe, de febrero de 1940 a abril de 1947, según consta en su ficha de la Asociación de la Prensa de Madrid.

11 Entrevista, 12 de diciembre de 2013.

12 Entrevista, 31 de mayo de 2014.

13 Entrevista, 28 de febrero de 2014.

14 Ídem.

15 Entrevista, 23 de mayo de 2014.

16 Entrevista, 28 de abril de 2014.

17 Testimonio escrito remitido, 30 de mayo de 2014.

18 Entrevista, 31 de mayo de 2014.

19 Archivo Fundación Nacional Francisco Franco (AFNFF), documento 7669.

20 AFNFF, documento 20476.

21 AFNFF, documento 1592.

22 Entrevista, 12 de diciembre de 2013.

23 Entrevista, 4 de junio de 2014.

24 Entrevista, 31 de mayo de 2014.

25 AFNFF, documento 776.

26 Entrevista, 12 de diciembre de 2013.

27 Entrevista, 28 de febrero de 2014.

28 Ídem.

29 José María de Llanos Pastor (1906-1992) primero falangista, se convirtió luego cura obrero afiliado al PCE.

30 Entrevista, 31 de mayo de 2014.

31 Entrevistas, 12 de diciembre de 2013 y 17 de enero de 2014.

32 Entrevista, 23 de mayo de 2014.

33 Testimonio escrito, 30 de mayo de 2014.

34 Entrevista, 14 de junio de 2014.

35 AFNFF, documento 9260.

36 AFNFF, documento 9967. Las citas del párrafo pertenecen a este texto.

37 AFNFF, documento 12352.

38 AFNFF, documento 12596, hoja 1.

39 Ídem, hoja 2.

40 AFNFF, documento 15207. 
41 AFNFF, documento 7274.

42 Entrevista, 23 de mayo de 2014.

43 Entrevista, 13 de diciembre de 2014. 